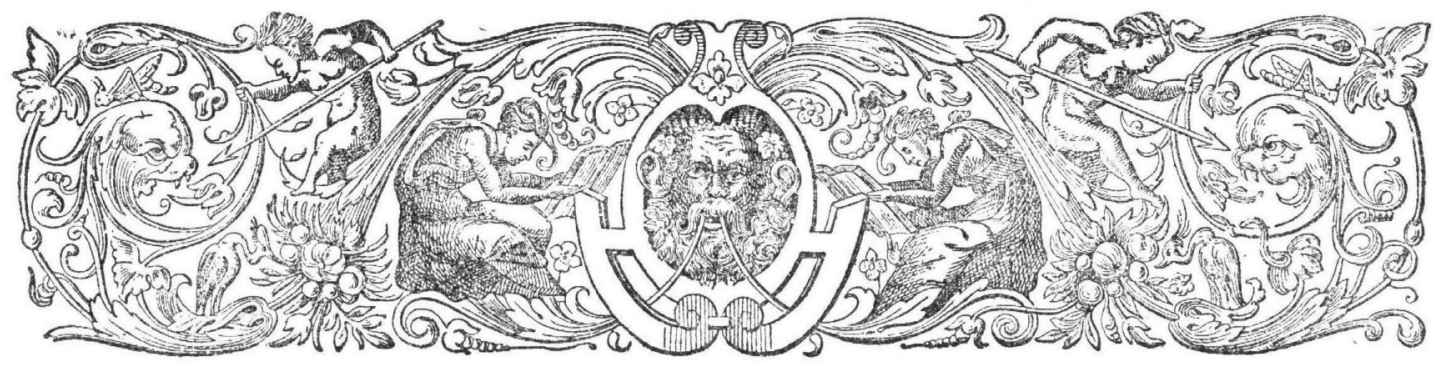

\title{
BALTHAZAR GERBIER
}

DODR

DR. M. G. DE BOER.

„Al decse hooghe eer vercreegh hij door Pictuur, Doch hij oock meester was in d'eel Architectuur, In Mathematica en in Gheometrie Seer fraai in Perspectief en oock Cosmosraphie, En in Geographie een wonder inseigneur Jae in veel consten meer een geestigh inventeur".

OEN CORNELIS DE BIE in zijn "Gulden Cabinet" ') de verdiensten

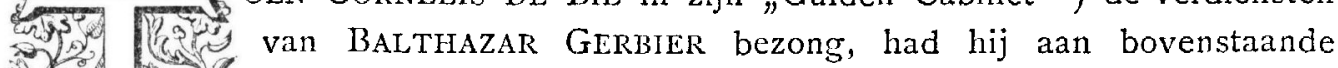
8. 21 opsomming van 's mans voortreffelijkheden nog gerust het een tof lo en ander kunnen toevoegen, zonder de waarheid te kort te doen.

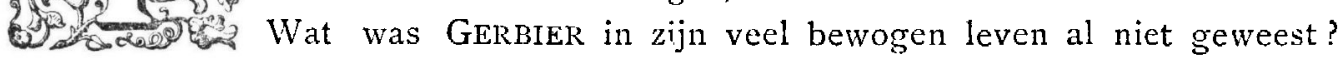
Begonnen als schilder en beoefenaar der „edele penneconst”, voelde hij weldra roeping voor ide diplomatie en vertegenwoordigde jarenlang den Engelschen koning aan het Brusselsche hof, daarbij ruimschoots gelegenheid vindend om toe te geven aan zijn zucht tot intrigeeren. Na zijn ontslag als diplomatiek agent was het de sociale questie, die zijn aandacht trok, en trachtte hij o.a. de belangen der armen en die van zijn eigen beurs door het oprichten van banken van

1) Antwerpen I66r, pag. 248, met portret van Gerbter naar van Dijck.

Oud-Holland, 1903. 
leening te behartigen. Toen zijn plannen mislukten, wendde hij het fluks over een anderen boeg en richtte een hoogeschool op, waar hij de meest uiteenloopende vakken, zoowel de welsprekendheid als de stuurmanskunst, de cosmografie als de versterkingskunst doceerde. Voegt men hieraan toe, dat hij nog op 67jarigen leeftijd een goudmijn wilde ontginnen en een kolonie in Guyana gingstichten en zich ten slotte op de architectuur toelegde, neemt.men daarbij in aanmerking, dat hij temidden van zooveel beslommeringen tijd vond voor het schrijven van verhandelingen over de haringvangst en over helsche machines, over de laken. nering en de bouwkunst, over politick en over het stelsei van COPERNiCUs, dan zal ieder mij toestemmen, dat men hier van een welbesteed leven zou kunnen spreken, als niet het spreekwoord: "twaalf ambachten, dertien ongelukken" ons waarschuwend voor den geest stond ${ }^{1}$ ).

BALTHAZAR GErbien werd in het voorjaar van 1592 te Middelburg geboren, waar zijn ouders zich sedert kort gevestigd hadden. De kwellingen, waaraan de Hugenoten tijdens de insluiting van Parijs door HeNdRIK VAN NAVARRE van de zijde der Katholieken blootstonden, hadden ANToine Gerbien deen besluiten de hoofdstad van Frankrijk te verlaten en zich in de Republiek te vestigen ${ }^{2}$ ).

Hct was geen tocval, dat hij zich Middelburg als woonplaats koos. Reeds in den aanvang der I6de eeuw had daar zijn grootvader, eveneens ANTOINE geheeten, aunzienlijken handel gedreven; zijn clochter IsABEAU was claar in 1535 in het huwelijk getreden met PIFrre DE MOUCHERON, pas uit Normandië naar de hoofdstad van Zeeland gekomen ${ }^{3}$ ). Toen echter ANToine kort na het huwelijk zijner dochter overleed, blcek zijn inboedel zoo bezwaard, dat zijn weduwe huiverig was de erfenis te aanvaarden en de sleutel op de kist legde. De zoon, de vader van bovengenoemden ANTOINe, verliet daarop Middelburg en keerde vermoedelijk naar Frankrijk terug. DE MOUCHERoN verplaatste kort daarna zijn zaak naar het snel opkomende Antwerpen, waar het handelshuis, vooral onder BALTIIAZAR DE Moucheron, tot grooten bloei kwam.

1) Deze studie heeft zijn ontstaan te danken aan een opmerking van wijlen Prof. Frurs, die mij na het verschijnen inijner dissertatie schreef: „Zoudt ge geen lust hebben, nu ge $U$ al zooveel met GERBIER bemoeid hebt, zijn gansch avontuurlijk leven eens te beschrijven? Als voorbeeld van het leven van een toenmaligen diplomatieken avonturicr zou het niet van belang ontbloot zijn", en mij een aantal aanteekeningen ten gebruike afstond. Dat deze aanteekeningen mij van groot nut waren, behoeft geen betoog. Ook van andere zijde ondervord ik bij het verzamelen der zeer verspreide bouwstoffen vriendelijke hulp, in 't bijzonder van Dr. A. A. Bi:edrus, Prof. H. Brugmans en Prof. C. H. Th. Bussemaker; daarvoor mijn hartelijken dank. Veel nut had ik verder van het uitnemende artikel over Gerbier, in de Dict. Nat. Biogr. Met de letters K. B. gaf ik aan, dat de geciteerde pamfletten in de Kon. Bibl, aangetroffen worden.

2) Manifeste du Chevallier Balth. Gerbier: Thysiana 2258. Sainsbury: Original Papers of Rubens, 326.

3) DE StoppelaAr: Balthazar de Moucheron. I3. Ook de Gerifirs waren vermoedelijk uit dezelfde streken afkomstig; nog larg daarna leefde te Rernes een familie van dien naam. 
Toen ten tweeden male een lid der familie GERBIER zich te Middelburg ging vestigen, waren de Moucherons weer in deze stad teruggelecrd, daar de inneming van Antwerpen door PARMA hun als Protestanten verder verblijf in die stad onmogelijk zou hebben gemaakt, ook al hadden de Zeeuwen den weg naar zee niet afgesneden. De vluchtelingen werden door hen gastvrij ontvangen; bij den doop van hun zoontje, welke den I $2^{\text {en Mart }}$ I 592 in de Waalsche kerk plaats vond, trad BALTHAZAR DE MOUCHERON, naar wien de jonggeborene genoemd werd, als getuige op.

Evenmin als zijn grootvader werd ANTOINE, die zich als zijdewever en koopman vestigde, door de fortuin begunstigd. Bij zijn dood in 't jaar I 598 bleek het, dat hij aanzienlijke sommen zoowel aan voorgeschoten geld als voor geleverde goederen aan zijn verwanten schuldig was. Naar allen schijn is de familie kort daarna uiteengespat; de kleine BALTHAZAR werd althans door een ouderen broeder naar Zuid-Frankrijk gebracht, waar hij te Bordeaux cen aantal jaren doorbracht ${ }^{1}$ ).

We weten niet, wanneer de jonge GERBIER weer in ons land teruggekeerd is, evenmin is ons iets bekend over zijn opvoeding en leermeesters. Misschien zou men uit het feit, dat hij na den dood van GoLTzIUs een hoogdravend „Eer- ende claghtdicht ter eeren van den lofweerdighen, constrijcken ende gheleerden schilder, plaetsnijder ende meester van de penne" in het licht gaf, kunnen opmaken, dat er tusschen GERBIER en GoLTzIUS een nadere betrekking zou hebben bestaan. $\mathrm{O} p$ de vraag, of Gerbier misschien onder Goltzius' leiding heeft gestaan, geeft het gedicht geen antwoord ${ }^{2}$ ).

Toch geeft het gedicht ons enkele nuttige aanwijzingen. Bij enkele schrijvers vindt men het vermoeden uitgesproken, dat GERBIER, zooals zoo vele andere schilders, een reis naar Italië zou hebben ondernomen. In het Eer- ende Claghtdicht waarschuwt hij echter jonge kunstenaars bepaaldelijk om Italië te

1) Het vertrek der GEkbiers zal vermoedelijk ook in verband gestaan hebben met de slagen, die in dit tijdperk de Moucherons troffen (zie DE STOPpelaAR t.a.p. aanteekeningen 26). Het jujste tijdstip is niet bekend. In 't pamflet uit de Thysiana 2258 zegt GerBIen, dat hij 6 jaren oud naar Bordeaux ging elders (Sainsbury 3I6) spreekt hij van 8jarigen leeftijd. Daar hij ook mededeelt in 't jaar I600 te Middelburg te zijn geweest, toen MaUkiTs en FredERIK HeNDrik, dien onoverwinnelijcken Mars ende dien Phoenix der hclden uit den heerelijcken slag in Vlaanderen" terugkeerden, schijnt mij de tweede opgave het meest waarschijnlijk (Aenmerckinge ende doen van Keysers, Koninghen enz. Hs. Oranje-Nassau boekerij in de Kon. Bibl. No, r7o).

2) Het gedicht, waarvan het eenige mij bekende exemplaar in de stedelijke bibliotheek te Haarlem berust, is in I620 te 's Gravenhage gedrukt. G. klaagt daarin zeer over de onverschilligheid der Haarlemmers aangaande GolTzIUS; zij hadden diens lijk, in de aerde ghedouwt sonder dat yemant lesen kan, waer hij leyt." Het lofdicht, waarvoor hij te Haarlem geen uitgever kon vinden, werd ook pas twee jaar later in 's Gravenhage gedrukt. Zijn eigen dichterlijke gaven schatte hij overigens niet hoog: „De studie van andere ronsten myn soo te werck stellen, dat ick geen tijdt en hebbe om op den bergh der musen te climmen". 
bezoeken, waaraan men volgens hem gewoonlijk veel te groote waarde toekent, "die een esel gaet, niet licht weer keert een peert".

Alleen de Tiber herinnert in Italië volgens hem nog aan de Oudheid:

"al wat in Romen staet syn hout' en steenen baken, Die onse koustenaars doen op een doolwegh raecken. $O$ ghy leergierge jeught

Slijt niet dijn duren tijt om dees afgoon te prijsen!"

Nemen we nu in aanmerking, dat GERBIER, die zoo prat gaat op alles wat hij beleefde, nergens van een reis naar Italië spreekt, dan kunnen we deze gerust op rekening van de verbeeldingskracht der bedoelde auteurs stellen.

Uit een andere passage blijkt, dat GERBIER groote bewondering voor de dochters van ROEMER VISSCHER gevoelde, voor ANNA,

De bloem van Nederland, wiens naem niet sonder roemen En can syn uytghedruckt

en voor, ,jouffrou Tessie Schae,

"Der Godtheyts schepsel reyn en spicghel van de Deught;

TESSEL en ANNa twee nymphen sijn in 't kort

In wie de Hemel heeft de gratiën al ghestort."

Het eerste stellige bericht, dat wij omtrent GERBIER vernemen, is, dat hij omstreeks $16 I_{5}$ in dienst was van Prins MAURITS. Volgens sommigen zou hij diens aandacht hebben getrokken door zijn kennis der versterkingskunst; mij komt het daarentegen waarschijnlijker voor, dat hij eerst in dienst van MAURITS die oppervlakkige noties van de krijgskunde opdeed, welke hij in later jaren productief zocht te makei. Waarschijnlijk is hij gewoon als klerk of schoonschrijver bij MAURITS in dienst geweest, in laatstgenoemde qualiteit althans voelde nij zich ook bevoegd om GolTzIUs te beoordeelen. Zooals een matroos het meeste verstand heeft van zeilen,

"soo spreeck ick dan met recht.

Dat ick van jonckheyt af de Penn heb leeren mennen

En die daer in mijn tijdt sich med' gheoeffent heeft

Verstaet oft ick wel weet, wat arbeyt dat sij gheeft

Om d'allerhoochste vaen van haren top te haelen."

Pen-kunstenaar toonde hij zich ook, toen hij in 1615 „Syn Excellentie seer pertinentelijck metter penne heeft afgetrocken." Voor het exemplaar, dat hij aan de Staten-Generaal zond, werd hem een vereeringe van honderd guldens geschonken ${ }^{1}$ ). In denzelfden tijd zou hij ook een medaillon-portret van den Prins

1) Resolutièn der Staten-Generaal, 2 I Febr. $x^{6} I_{5}$, bij Dodt: Tijdschrift VI 363 . 
geschilderd hebben, dat enkele jaren geleden op een verkooping voorkwam, maar waarvan het tegenwoordig verblijf mij onbekend gebleven is ${ }^{1}$ ).

GERBIER is echter slechts kort in dienst van den Prins gebleven; in I6I7 nam hem, wellicht op diens aanbeveling, de Staatsche gezant te Londen, NotL DE CARON, mede naar Engeland, waar hij ook aanvankelijk als calligraaf schijnt te zijn opgetreden; zoo vervaardigde hij voor de Hollandsche kerk te Londen de Tien Geboden, waardoor naar 't schijnt de aandacht op hem werd gevestigd ${ }^{2}$ ).

Weldra had GERBIER het geluk in aanraking te komen met GEORGE DE VILLIERS, hertog van Buckingham. De prachtlievende gunsteling van JACOBUS I kon juist iemand als GERbIER, die zich op allerlei gebied wist te bewegen, in zijn dienst gebruiken; hij werd belast met het maken van plannen voor tooneelvoorstellingen en gemaskerde feesten; verder werd hem de zorg opgedragen voor de kunstverzamelingen van York-house. Weldra stond hij zeer in de gunst bij den hertog, die hem herhaaldelijk voor vertrouwelijke zendingen gebruikte en hem als "master of the horse" meenam op de bekende reis naar Spanje, waar hij voor den jongen KAREL de hand der Infante ging vragen.

Tegelijkertijd legde hij zich toe op het schilderen van miniaturen, waarin hij zich weldra zeer bekwaam toonde ${ }^{3}$ ). Herhaaldelijk schilderde hij zijn beschermer, o. a. tijdens diens verblijf in Spanje op verlangen der hertogin; ook heeft hij daar voor JACOBUS I het portret der Infante geschilderd. South Kensington Museum bezit o. a. een miniatuur-portret in grisaille van KAREL I; het Britsch Museum een met de pen op perkament ${ }^{4}$ ), beide van de hand van GERBIER.

De reis naar Spanje had hem natuurlijk ook met den Prins van Wales in aanraking gebracht, die weldra als KAREL I den troon beklom. De kunstlievende

1) Zie de Catalogus van bouken van van Dam van Nooñdeloos, p. I8I No. I, waar van een geschilderd portret spralie is. In strijd daarmee is de verklaring van Gerbier aan Buckingilam, dat hij zich eerst in Engeland op de schilderkunst had toegelegd: "Je jure devant Vieu. que jamais je ne fus peintre, avant que de m'être placé sous vorre patronage en quittant le prince d'Orange (Hookham Carpenter: Mémoires et documents inédits sur AnToINE van Dijck etc. op gezag van Goodman: La cour de St. James, uitgegeven door BREwer II 397).

2) Zie Walpole: Anecdotes of Painting i. v. Gerbier, waar men een citaat uit SANDERsox's Graphice vindt. Hier worlt G. genoemd: ,a simple penman, who pensiled the dialogue (lees decalogue) in the Dutch Church, his first rise of preferment."

3) Reeds DE BIE, Gulden Cabinet (Antwerpen, IE6I) schrcef van Gerbier $n$ il a faict merveille on illuminature". Naar aanleiding van een manuscript te Cambridge: Robes, manteaux, armes d'empereurs, roys, papes, princes, ducs et comtes, blasonnés et esluminés par B. Gelrbier, zegt FÉTIS (t. a. p. I 233) "dat het stuk bewijst à quel haut degré il porta la délicatesse du pinceau". Dr. BReduus spreekt ook van een prachtig miniatuur-portret dat met G.'s naam gemerkt was (Nederl. Spect, 20 Jan. Igoo). Van zijn vaardigheid met de pen getuigen nog vele handschriften, waarvan de Kon. Bibl, er een enkel bevat.

4) Zie WAAGEN; Galleries and cabinets of arts. Suppl. 42. Het portret van den Winterkoning wordt beschreven als $\eta^{\text {in }}$ an oval form with tasteless decorations, extremely delicate but somewhat stiffy done". Zie verder Hookham Cakpenter: Mémoires et documents inédits sur Antoine van Dijck, Rubens etc. (1845) pag. 59 . 
koning deed hem zelfs de eer aan met zijn gemalin een bezoek aan zijn woning te breingen, teneinde daar eenig schilderwerk te bezichtigen, dat volgens de beschrijving als een voorlooper onzer panorama's zou kunnen gelden. Volgens WALPOLE, wiens berichten echter onder voorbehoud dienen te worden grebruilit, zou GERBIER toen den koning een souper hebben aangeboden, dat hem wel duizend Pond kostte.

Ook op een ander gebied bewees GERBIER een bruikbaar dienaar te zijn. Toen Buckingiam met een Engelsche vloot La Rochelle, dat door een Franschen koning werd belegerd, trachtte te ontzetten, vervaardigde GERBIER plannen voor een helsche machine, warmede hij den dijk, die de verbinding van La Rochelle met de zee afsneed, wilde vernielen. Naar het schijnt hebben hem daarbij de vuurschepen van Antwerpen voor den geest gestaan. Tot uitvocring is het echter niet gekomen, daar BUCKINGHAM, op 't punt staande om met de vloot te vertrekken, door Felton werd vermoord, waardoor de geheele onderneming opgegeven werd.

Weldra kwam er echter gelegenheid voor GERBIER om zich op een ander gebied te bewegen, dat meer met zijn neigingen overeen kwam. Het afwijzen van hethuwelijksaanzoek had Engeland in oorlog gebracht met Spanje; de zaak van La Rochelle had tot een lirijg met Frankrijk geleid. In gewone tijden zou het den koning reeds moeilijk gevallen zijn hiervan de kosten te dragen; met het pariement waren echter moeilijkheden uitgebroken, zoodat den konirg geen gelden werden toegestaan. Het was daarom noodig zoo spoedig mogelijk vrede te sluiten en bij het aanknoopen van onderhandelingen bleek GERBIER weldra een geschikt werktuig te zijn.

Reeds in I625 maakte GERBIER, toen nog kortweg "the duke's servant" genoemd, te Parijs kennis met een anderen schilder, die zich gaarne op het veld der diplomatie bewoog, met RUBENs, die toen het portret van Buckingiram schilderde. Hij bleef met dezen in correspondentie en kocht o. a. voor zijn meester een prachtige collectie oudheden en rariteiten, welke RUBENS bijeen gebracht had. Er was echter een andere zaak, die RUBENS zoowel als GERBIER zeer ter harte ging; niet tevreden met hun positie als schilder, zochten beiden als diplomaat naam te maken door een vrede tusschen Engeland en Spanje tot stand te brengen. Verschillende brieven werden.tusschen hen gewisseld ${ }^{1}$ ) ; het treffen van een regeling was echter niet gemakkelijk, daar KAREL zich verplicht achtte de Pfalz aan zijn zwager, den Winterkoning, te doen teruggeven, wat Spanje niet op zich kon nemen; ook had Engeland pas een verbond met de Republiek gesloten, die men dus in den vrede zou moeten betrekken.

Onze schilders gaven evenwel den moed niet zoo licht op en in Juli van

1) Zie voor deze briefwisscling Sainsbury: Original Papers of Rubens (London 1853), passim. 
het jaar 1627 ontmoetten zij elkaar in Holland ${ }^{1}$ ), waar zij onder het voorwendsel van over kunstzaken te spreken en schilderijen op te koopen, te samen een aantal Hollandsche stederi bezochten, en ook conferenties hadden met den Engelschen gezant CARLETON, Reeds streelden zij zich met de hoop hun doel te zullen bereiken, toen tot beider groote ergernis het bericht in de Nederlanden kwam, dat Frankrijk ei Spanje zich nauw aaneengesloten hadden, en er dus ggeen sprake van was, dat de eischen van KAREL I ingewilligd zouden worden. Diep teleur. gesteld kecrde GERBIER eindelijk in October 1627 naar Engeland terug.

In het volgend jaar trof hem een zware slag door den dood van zijn beschermer Buckingham, dien hij nog jaren claarna roemde als een volmaakt edelman, minzaam, hoffelijk en vrijgevig, edelmoedig en dapper, „esprit généralement capable de toutes choses nobles, amateur de toutes les sciences et le Mécenne des vertueux." 2) Daar hij inmiddels gehuwd en spoedig met een talrijk gezin gezegend was ${ }^{3}$ ) kwam hij nu in groote moeilijkheden. Nog in het volgende jaar klaagde hij, dat hij als loon voor zijn diensten, niets had gekregen dan een jaargeld, het oude huis waarin hij woonde en zijn post in York-house, "een soort dienstbaarheid" waaraan volgens hem geen noemenswaardige voordeelen verbonden waren, terwijl, wat het ergste was, de executeurs van het testament van BuCkINGHAM hem ook het eenige, wat deze hem geschonken had, wilden ontnemen, onder voorwendsel dat hij als vreemdeling geen rechten kon laten gelden.

Gelukkig nam de koning hem in zijn bescherming. Nog in den zomervan I628 legde hij aan het Parlement een wetsvoorstel tot naturalisatie van GERBIER voor, dat niet zonder heftigen tegenstand, daar deze als dienaar van BuckinGHAM veel vijanden had, werd aangenome:l.

De kansen op vrede waren inmiddels weer grooter geworden. De zware slagen, die Spanje in de jaren 1628 en '29 had ondervonden, deden Philips IV overhellen tot een vrede met Engeland, terwijl KAREL, I door de twisten met zijne vertegenwoordiging zoodanig in zijn politiek gehinderd werd, dat hij begreep

1) In den aanvang van dat jaar had GERrier eerst een reis naar Frankrijk ondernomen om daar den

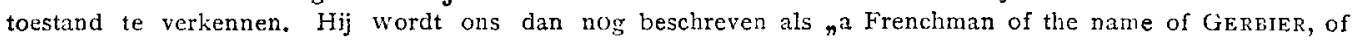
too ordinary a station and of too little authority", om iets te kunnen bereiken. (Hist. Man. Comm. XIth th Rapport App. I, r 05).

2) Les effets pernicieux des méchans favoris (den Hang, r653) K. B. In dit geschrift, waarop ik later terug kom, wijst hij ook op minder gunstige eigenschappen van zijn beschermer "facile à se laisser tromper par des donneurs d'avis creux, extrèmement amoureux, passion qui luy procura de grands ennemis dedans $e_{t}$ dehors le royaume. G. schijnt hier het oog te hebben op een passie van B. voor Anne d'Autriche en hierin een oorzaak voor den oorlog met Frankrijk te zien.

3) Zijn vrouw heette Deboran KIP of vaN Kip en was 5 Sept, roor gedoopt in Austin Friars Church (Moens: Marriage, bap̈tismal and burial registers of the Dutch reformed church of Austin Friars.) In 1627 was hij reeds gehuwd; in 1628 werd bij afwezigheid van Gerbiér een hem toekomend bedrag aan MIr. KI zijn schoonvader, uitbetaald. Later spreekt G. nog herhaaldelijk van my father-in-law KIP, 
voorloopig althans zijn eisch tot restitutie van de Pfalz aan zijn zwager te moeten laten varen. Onder dergelijke omstandigheden konden de onderhandelingen met uitzicht op succes weer aangeknoopt worden. Nog altijd stond GERBIER in relatie tot RUBENs en de Vlaamsche schilder, die altijd geneigd was het palet voor de pen te laten rusten, stond aanstonds gereed om naar Londen over te steken, waar hij in den voorzomer van I629 aankwam en zijn intrek nam bij GERBIER. $\left.{ }^{1}\right)$ Deze hoopte, dat de onderhandelingen, waarmede hij een begin had gemaakt, ook verder aan hem opgedragen zouden worden en toonde zich zeer geërgerd, toen deze geheel buiten hem omg!ngen en hem alleen de eer beschoren was "to be the inkeeper to RuBENs".

Hoe hij toen reeds zichzelf overschatte, blijkt uit een brief aan een der ministers, waarin hij zijn beklag deed en verzekerde, dat hij in trouw en betrouwbaarheid bij niemand achter stond en dat het onbillijk was om hem alleen de lasten der onderhandeling te doen dragen. De koning had van hem een ring gekocht, dien hij RUBENS ten geschenke wilde geven; ook had hij een belangrijke som voor diens huisvesting te vorderen: "God knows when GERBIER will be paid". Het bleek echter, dat hij ditmaal te zwaartillend was geweest; drie dagen na het verzenden van dezen brief kreeg hij niet alleen betaling voor de huisvesting van RUBENS, maar ook voor de kostbaarheden, die de koning van hem gekocht had om aan RUBENS te schenken, te zamen tot een bedrag van 628 Pond.

Ook nu nog schijnt GERBIER niet, zooals hij hoopte, met staatkundige zendingen belast te zijn; de koning gebruikte hem vooral voor onderhandelingen over aankoop van kunstwerken; herhaaldelijk wordt zijn naam genoemd in contracten tot levering van schilderijen of beeldhouwwerk. Met RUBENS sloot hij in deze dagen een innige vriendschap, welke hem later van groot nut is geweest. Ook met VAN DIJCk, die door den koning naar Engeland was geroepen, was hij bevriend; volgens sommigen heeft deze omstreeks 1630 een familiestuk geschilderd, waarop Gerbier met zijn vrouw en negen kinderen afgebeeld is ${ }^{2}$ ).

In het jaar I63 I werd een lang gekoesterde wensch van Gerbier vervuld; KAREL $I$ benoemde hem tot zijn vertegenwoordiger aan het hof der Infante te

1) $\frac{17}{27}$ Mei 1629 wachttc Rubens te Duinkerken op een pas; daar hij "mychitely affiayit of the Hollanders" was, durfde hij alleet op een Engelsch schip de zee oversteken.

2) De familiegroep, waarvan het origineel te Windsor hangt, wordt te onrechte met de namen van RUBENS of VAN DYCK in verbinding gebracht, al plaatste WILLIAM WALKER den naam van den tweede onder de gravure die hij in 5766 van het stuk maakte, en al had JAMES MC. ARDELL in 1755 onder een fraaie zwartekunstprent, waarin alleen de linksche groep, de vrouw met vier kinderen, laten drukken „The original Hicture by Sr. Peter Paul Reubens in the Collection of Samson Gideon Esqrat Belvidere in Kent". Een dergelijke groep werd in Igo2, als voorstellende de familie van den Hertog van Buckingliam geschilderd door Rubens, door Mevr. Hanbury op de Winter-Exhibition te Londen ingezonden. Anthonie van Dijck heeft echter in I634 GERBIER toch geschilderd, blijkens de prent die PAULUs PonTiUs naar dit portret gesneden keeft. - Red. 
Brussel. Ot hij dit deed uit vertrouwen op GERBIFRs diplomatieke bekwaamheden, dan wel om bij zijn onder handelingen met de Vlaamsche schilders partij te kunnen trekken van GERBIERS relaties en vakkennis, waag ik niet te beslissen; een feit is het evenwel, dat een belangrijk deel van GERBIERs werkzaamheden op kunstzaken betrekking hadden. Niat altijd waren deze bemoeiingen van aangenamen aard. KAREL I was nu eenmaal cen slecht financier en hield bij zijn ankoopen niet altijd rekening met den staat van zijn kas. Zoo had hij tijdens RUBENS' verblijf in Engeland den grooten kunstenaar opdracht gegeven voor het vervaardigen van schilderijen ter versiering der "Banquetting-Hall" in White-hall. Deze waren den I Aug. 1634 gereed gekomen, maar de koning zag geen kans om de vastgestelde 3000 Pnd bijeen te krijgen. Zonder geld levercle RUBENS ze evenwel niet af, merkte GERBIER op, die er zeer ontstemd over was, daar de zaak algemeen de lachlust opwekte. Toen eincielijk in den zomor van het volgende jaar geld beschikbaar was, bleek het onmogalijk de schilderwerken af te leveren, daar ze cloor het langdurig oprollen beschadigd waren. Eerst in Sept. 1635 konden ze worden overgezonden en toen liet weer de betaling, die in termijnen geschiedde, nog lang op zich wachten. Ecrst $2 \frac{1}{5}$ jaar na cle voltooiing van zijn werk zag RubENs zich in het bezit der volle som ${ }^{1}$ ).

Een anderen keer gold het de versiering van het kabinet der koningin te Greenvich, welke hij aan RUbens wilce opdragen, terwijl van andere zijde JORDALNS werd aanbevolen. Beiden achtte hij in zooverrehoog, dat zij niet mede gingen met het realisme van andere schilders en viet hun liraclut zochten in "robustrous, boistrous, druncken-headed imaginary Gods." Waar echter JORDAENs en RUBENS ongeveer gelijke prijzen vroegen "), vond hij RUBENS het meest aanbevelenswaardig: "the most gentilest in his representations, his landskippes more rare and all other circumstances more proper". Evenwel, voest hij op schalksche wijze toe, zinspelende op de geschiedenis van de Banquetting-hall, „painters pencills move not without nusick". De opdracht werd toch aan JoRDAENs gegeven, misschien, omdat zijn prijs ten slotte slechts de heltt van die van KUEENs bleek te bedragen ${ }^{2}$ ).

Zijn ambt te Brussel gaf GLRBIER echter tevens een uitstelende gelegenheid om toe te geven aan zijn behoefte tot intrigeeren. De tijdsomstandigheden leenden zich daartoe bijzonder. Het wanbestuur der Spanjaarden, het plunderen der onbetaald gebleven troepen, die onbekwam bleken om het land tegen de wapenen van FREDERIK HENDRIK te verdedigen, de begunstiging van Spanjaarden boven den inheemschen adel, had de bevolling der Zuidelijke Nederlanden tot

1) Sainsbury: t. a. p.: I April 1634, ro Juni, 17, 31 Juli 3,5 en 28 Sept. I6 35.

2) SAINSBURY: t. a. p. 25 Jan. 1640 .

Ond-Holland, 1903 . 
wanhoop gebracht. Daarbij kwam het vooruitzicht, dat bij den dood der reeds zeer bejaarde Infante elke zweem van zelfbestuur verloren scheen te zullen gaan. Bij enkele edelen kwamen nog persoonlijke grieven de ontevredenheid verorooten en in het begin van 1632 traden graaf HENDKIK VAN DFN BERG en de graaf VAN WARFUSEE in geheime onderhandeling met den vijand, om, toen FRLDERIK HENDRIK met zijn troepen langs de Maas zuidwaarts rukte, openlijk van de Spanjaarden af te vallen en de plannen van den Prins in de hand te werken. Venlo en Roermond gingen reeds na enkele dagen over; in vertrouwen op den steun van graaf VAN IDEN BERG sloeg FREDERIK HENDRIK het beleg voor Maastricht. Was het onder dergelijke omstandigheden te verwonderen, dat de belgische adel cr ernstig aan ging denken om door een verdrag met den vijand althans het behoud van de rechten des lands en van de Katholiekekerk te verzekeren ${ }^{1}$ ).

De verwachte opstand bleef echter uit. Allerlei oorzaken droegen hiertoe bij, het meest wel het feit, dat het hoofd van den adel, de hertog vas AERschot, op het punt staande Brussel te verlaten, zich door de smeekingren der Infante liet bewegen haar te blijven steunen. Toch bleef de toestand hachelijk genoeg, vooral toen alle pogingen om Maastricht te ontzctten mislukten, en de stad in handen van FREDERIK HENDRIK viel, die nu het hart van het land bedreigde en in een manifest de Belgen opriep om zich te bevrijden. Toen de Infante, bevreesd voor algemeenen opstand, eindelijk de Staten-Generaal bijeen riep, ging er van dit lichaam een krachtige aandrang uit om vrede met het Noorden te sluiten, het mocht dan kosten, wat het wilde. Daar nu de Prins van Oranje herhaaldelijk en met klem verzekerde, dat het Noorden uitsluitend met de Belgen, niet met den koning van Spanje wilde onderhandelen, was het niet ondenkbaar, dat de opstand toch nog zou uitbreken.

Met belangstelling had GERBIER gedurende den zomer van $16_{32}$ den loop der gebeurtenissen aangezien; zijn onderhoudend geschreven depêches zijn voor de kennis van dit tijdperk van veel beteekenis. Maar hij bepaalde zich niet tot de rol van toeschouwer en trad al spoedig in relatie tot de ontevreden edelen, die na het terugtreden van AERschot niet durfden door te tasten. Volgens GERBIER zou de eerste stap van de zijde der edelen gedaan zijn; op een nacht was een edelman, door een masker onkenbaar gemaakt, bij hem gekomen om de bescherming van den Engelschen koning in te roepen tegenover de Nederlanders en Franschen, die het land dreigden te veroveren.

$\mathrm{Nu}$ leefde KAREL I in vrede met PhILIPS IV van Spanje; beide vorsten waren zelfs nauw verbonden. Toch ging hij in op de voorstellen van GERBIER

1) DE BoER: Het verraad van graaf Hendrik van den Berg en de veldtocht langs de Maas, Tijd. schrift voor Geschiedenis 1898 . 
en gat hem volmacht nader met de edelen te onderhandelen en hen tegenover ieder, den Spaanschen koning uitgezonderd, bescherming te beloven. Weldra ging hij echter een stap verder en machtigde GERBIER het ontstaan van een Engelschgezinde partij in de hand te werken en niet alleen den adel, maar ook de geestelijkheid en het volk op de voordeelen opmerkzaam te maken, die een aansluiting bij Engeland kon meebrengen ${ }^{1}$ ). Te eerder kwam hij hiertoe, omdat PHILIPS IV een voorstel om de Vlaamsche havens aan Engeland af te staan, waarvoor Engeland de rest van het land zou helpen verdedigen, met beslistheid had afgeslagen.

GERBIER maakte een ruim gebruik van zijn volmacht; in zijn huis hadden herhaaldelijk des nachts bijeenkomsten der ontevredencn plaats. Hij ging nog verder en wist een pas te verkrijgen zoo het heette om den Prins van Oranje over vrede te polsen. Te Luik onderhandelde hij eerst met WARFUSEE en EGMOND, die openlijk tegen de regeering in opstand waren gekomen. Hij moedigde hen aan bij Engeland, niet bij Frankrijk steun te zoeken; daarna hat hij in het kamp te Maastricht een samenkomst met Oranje.

Voor de persoonlijkheid van GERBIER ${ }^{2}$ ) is zijn houding in deze dagen bijzonder karakteristiek. Zooals wij zagen, had hij voortdurend moeite gedaan om de ontevredenen te weerhouden zich aan het Noorden te onderwerpen en hun daarvoor de ondersteuning van KAREL I voorgespiegeld. Oranje daarentegen, wien hij voorstellen tot vrede met Spanje moest doen, trachtte hij diets te maken, dat er in het Zuiden een talrijke partij gereed stond om zijn zijde te kiezen, wanneer hij maar standvastig weigerde onderhandelingen mot Spanje an te knoopen en de belofte wilde afleggen België als vrije staat te erkennen ${ }^{3}$ ).

Natuurlijk was Oranje niet de man, om de dupe te worden van een intrigant als Gerbier; uit diens brieven moet men echter opmaken, dat de Prins althans den schijn aannam op GERBIERs plannen te zullen ingaan. Toen het echter bleek, dat van een opstand niets te verwachten was, handelde hij naar omstandigheden en knoopte onderhandelingen aan met de Staten-Generaal van het Zuiden, daartoe door ISABELLA gemachtigd.

Het is hier niet de plaats om de onderhandelingen, die hiervan het gevolg waren, uitvoerig te schetsen; ik kan daarvoor naar mijn benedengenoemde studie over dit onderwerp verwijzen. Het zij genoeg erop te wijzen, dat GERBIER, die een voor de Republiek voordeeligen vrede niet in't belang van Engeland achtte, zooveel

2) Hardwicke State Papers II: 55, 79 en vlg. Zic verder mijn „liriedens-unterhandlungen". Groningen 1898 , pag. 39 en vlg.

2) Een typisch staaltje van zijn onbetrouwbaarheid geeft Salxsbury: t. a. p. I63. Hij had Rubens onder eede de geheimhouding van een zaak beloofd, deelde echter alles aan den koning mce, en meencie hicrtoe gerechtigd te zijn, daar hij niet beloof had, over de zaak niet te zullen $\mathrm{sch} r \mathrm{ij} v \mathrm{v}$.

3) Zie mijn Friedens-unterhandlungen zwischen Spanien und den Niederlanden, 43. 
hij kon, het treffen van een vergelijk trachtte te voorkomen. Hij bezwoer den Prins zijn belofte te Maastricht gegeven na te komen; nog nooit was een zaak hem zoo ter harte gegaan als deze; weigerde de Republick met den koning te onderhandelen, dan was een opstand zeker; in elk geval moest men sommige punten, waartegen de Spanjaarden vooral bezwaar maakıen, zonder voorbehoud handhaven ${ }^{1}$ ).

Tegelijkertijd zocht hij zijn regeering te bewegen stappen te doen ten behoeve der ontevredencn. KAREL I was naar het schijnt huiverig verder te gaan, maar gaf GrRbIER toestemming on de zaak persoonlijk te komen toelichten $\left.{ }^{2}\right)$. Het gevolg was eindelijlk, dat de gezant gemachtigd werd den edelen 's konings bescherming te beloven. Als men in opstanl kwam en hem een landingsplaats wilde afstaan, dan zou hij een leger zenden om hen tegen ieder "none excepted", dus ook tegen den Spaanschen koning, te verdedigen ${ }^{3}$ ).

Doch ook deze beloften hebben geen merkbarcn invloed gchad. Aan opstand dachten de Belgen minder dan ooit te voren. Na den val van Maastricht was de algemeene toestand merkbaar beter geworden door den dood van den $Z$ weedschen koning; bekwame en energieke mannen stonden de Infante ter zijde bij de verdediging van het land; het ergste gevaar was geweken.

Toen GERbIER inzag, dat zijn intriges tot niets zouden leiden, wendde hij het over een anderen boeg. Als vertegenwoordiger van den Engelschen koning had hij zich verplicht geacht een schitterenden staat te voeren; neemt men datrbij in aannerking, dat hij met een talrijk kroost grezegend was ${ }^{4}$ ) cn dat de geldzendingen uit Engeland wel eens uitbleven, dan is het niet te verwonderen dat een onbemiddeld man als GERBIER, die tevens slecht financier was, in groote moeilijkheden moest geraken. Hij had nu de laagheid, door bemiddeling van een tusschenpersoon aan de Spaansche regeering mede te deelen, dat hij bercid was mededeelingen te doen over de betrekkingen der Belgische edelen tot de regeeringen van de Republiek, Engeland en Frankrijk.

Voor het uitgeputte Spanje was de gevraagde geldsom, 20.000 Crusado's, aanvankelijk een bezwaar, temeer daar GERBIER de som enkel in specie wilde ontvangen en zich alleen bereid toonde tot het doen van mondelinge mededeelingen. $\mathrm{Na}$ eenige aarzeling besloot men echter zijn eischen in te willigen; het geld werd uit de legerkas genomen; op een nacht kwam cen monnik, gebogen onder den last van het goud, bij Gerbier om zijn confidenties aan te hooren

1) Zie hieiover den brief aan Oranje, uitgegeven door BRILL in Kronijk Hist. Gen. I867 en mijn Friedensunterhandlungen, Bijlage $\mathrm{I}$.

2) Het uitwoerige verslag, dat Gerbier toen van de gehcele onderhandeling uitbracht, is gepubliceerd in de Hardwicke Papers II 63 vlg.

3) Hardwicke Papers, II $9^{2}$

4) Hij had toen vijt dochters en drie zonen. 
De mededeelingen van GERBIER waren niet zoo belangrijk als de regeering vermoedde, toch gaven zij aanleiding tot gevangenneming van enkele voorname edelen als AERSCHOT en BARBANÇON, die lange jaren in hechtenis bleven; de andere slachtoffers wisten nog tijdig te vluchten.

De onbeschaamde driestheid van GERBIER spreekt duidelijk uit zijn houding na het verraad. Zelf berichtte hij aan zijn regeering, dat blijkbaar iemand den verrader had gespeeld en de onderhandelingen met de edelen aan de Spanjaarden had overgebriefd. "Voor mij zal dat een onangename toestand worden" schreef hij. „Mocht men er met mij over spreken, dan zal ik den storm kalm over mijn hoofd laten trelken, zooals het een diplomaat past, die wel is waar ooren heeft om te hooren, maar geen tong om op dergelijke zaak te antwoorden, tenzij zijn souverein hem zulks gelast" Om ook verder geen argwaan te wekken, zond hij enkele weken later een dringende aanvrage om geld naar Engeland, klagende dat hij in 3 jaar tijds uit eigen fondsen 2000 Pnd., in dienst van den koning had uitgegeven. In later jaren trachtte hij zooals wij later zullen zien de schuld van het verraad op den Engelschen minister CotTINGTON te werpen ${ }^{1}$ ).

Zijn verstandhouding tot de Spannsche regeering was trouwens niet altijd even goed. De last, die de Engrelsche koopvaarders van de Duinkerker kapers ondervonden, deed hem herhaaldelijk klachten richten tot de Infante en haar opvolgers. Reeds in 1632 schreef hij, dat Duinkerken op Algiers begon te gelijken ; de kiapvaart toch werd bevorderd door de gouverneurs der grewesten, dic er finantieel bij geinteresseerd waren. Kwam men met zijn klachten bij den rechter, dan was het dikwijls ook bij een gunstig vounis onmogelijk om restitutie van het geroofde te krijgen.

De rooverijen der Duinkerker kapers gaven nog in een ander opzicht tot moeilijkheden aanleiding. De Hollandsche visschers waren in deze dagen gewoon van Karel I paspoorten te koopen, waarbij hun de vrije uitoefening der visscherij in Engelsche wateren werd toegestaan. De Duinkerkers namen hiervan echter geen nota en vielen de Hollanders in de Engelsche wateren aan. Door omkooping der maitresse van den Kardinaal-Infant wist Gerbier ten slotte van dezen de belofte te verkrijgen, dat de paspoorten door hem erkend zouden worden; de Spaansche admiraal evenwel achtte zich hierdoor niet gebonden en liet de kapers hun gang gaan.

In het jaar $1638 \mathrm{kreeg}$ de Spaansche gezant te Londen last de terugroeping van GERBIER te eischen. De Engelsche regeering was echter niet genegen hierop in te gaan, daar GERBIER juist belast was met een zeer belangrijke onderhande-

1) Zie mijn Friedensunterhandlungen pag. I48, Over de "none-such Charles" en over de meening, dat GERBIER later aan KAREL I het verraad zou hebben ten laste gelegd, zie echter pag. I 46 van dit artikel.

Zie verder Thurloe-papers VII 275. Waddington: la République des Provinces Unies, la France et Jes Pays-Bas Espagnols, I $\mathbf{1} 75$. 
ling, die naar men hoopte tot teruggave van de Pfalz aan den zoon van den Winterkoning zou leiden ${ }^{1}$ ). Zoo tevreden was de koning toen nog over zijn diensten, dat hij GERBIER tot ridder sloeg, wat deze op hoogen prijs stelde daar het hem gemakkelijker maakte zijn dochters uit te huwelijken.

Maar de Spanjaarden lieten het er niet bij rusten. Na den slag bij Duins had er een scherpe woordentwist plaats tusschen den Kardinaal-Infant en GERBIER waarbij de laatste zich vrij heftig uitliet. Opnieuw werd met klem op terugroeping van den gevolmachtigde aangedrongen ${ }^{3}$ ); zij hadden zijn onbeschaamdheid lang genoeg verdragen, maar konden niet langer als gezant te Brussel een Hollander dulden, dien zij als rebel beschouwden.

Daarbij kwam nog, dat hij door lieden uit zijn eigen omgeving bij de Engelsche regecring zwart gemaakt werd. God pardon those, who recommend such ministers of state in such times as these," aldus GEORGE SHAwE in een brief aan Sir ThOmas ROE, "the State is very much afflicted at his being here." Een dergelijke stemming kon GERBIER natuurlijk niet verborgen blijven; hij begon meer en meer in te zien dat zijn dagen in Brussel geteld waren; in April I $6_{4}$ o schreef hij RUBFis, dat hij hem nog eens hoopte te ontmoeten, daar hij dacht spoedig te zullen vertrekken. "I calculate leaving this place, where I spent. nine years, much in misery, amongst men who do not understand them selves, much less others. It is best for me and mine tho choose another climate; Please God the great Cirarles will grant me such a thing". Enkele maanden later smeekte hij WINDEBANK om een plaats als postneester; hij was toen "in extreme need of somewhat to keep me floating."

Tegen het eind van het jaar I640 schijnt de Spaansche Regeering eindelijk een einde aan de zaak te hebben willen maken. Wij weten, dat GERBIER indertijd zoo voorzichtig geweest was, de Spaansche regeering alleen mondeling in te lichten over de samenzwering van den Belgischen adel. Zij bezat dus geen bewijzen, die zij tegen GERBIER kon uitspelen; cr kwamen echter geruchten in omloop, dat de hertog VAN Akrschot mededeelingen had gedaan, waardoor GERBIER zeer gecompromitteerd werd. Hij hield zich, alsof hij zich daardoor ernstig beleedigd gevoelde; ,I am expecting, with much devotion, to hear from Spain, what satisfaction the good king will give to the king my master on the false accusations of that stupid Duke of AFRschot", schrijft hij aan RUBENs. Hij schijnt echter zoo in het nauw gebracht te zijn, dat hij ten slotte tot een wanhopigen stap overging en brutaalweg de schuld van het verraad der bewuste

I). 25 Mei 1628. Windebank aan Gereikr (Sainsbury 317 ).

2). Gardiner. The fall of the Monarchy I 182 .

3). Clarendon State Papers II 83. 
samenzwering op den minister COTTINGToN wierp en dezen bij de "House of Lords" aanklaagde ${ }^{1}$ ).

In Juli I64 I werd de zaak voor het Hoogerhuis behandeld en GERiıek was niet in staat zijn beschuldiging waar te maken, daar twee zijner voornaamste getuigen hem in den steek lieten. Het gevolg was natuurlijk, dat hij niet in zijn ambt kon worden gehandhaafd en in de grootste moeilijkheden kwam. Gerbier can get neither countenance nor moncy, schrijft zijn gewezen secretaris uit Brussel naar Londen en deelt verder mee, dat hij zoo diep in de schulden zat, dat hij niet eens zijn familie kon laten weggaan. "Poor GERBIER is in bad predicament and must brooke it best, he may." Zijn familieleden zullen langzamerhand moeten vertrekken, al naar er geld komt om de schulden te betalen: "they shall creep away bij degrees.',

Ook nu nog bleef de koning, hoewel hij zeer ontevreden was, dit GERBIER, zonder daartoe verlof te vragen, met de aanklacht tegen CoTTINGTON voor den dag gekomen was, hem beschermen en benoemde hem tot "Master of Ceremonies", weil ambt hem reeds lang te voren schijnt te zijn toegezegd 2).

De bescherming van den koning kon hem echter weinig baten. De omwenteling stond uit te breken en bet was gevaarlijk als gunsteling vain den koning bekend te staan. Dit ondervond GERBIER, toen in Sept. 1642 zijn huis door het volk werd aangevallen, omdat men meende, dat hij cr katholieke priesters verborgen hield. Verontwaardigd vaardigde hij een pamflet uit: "a wicked and inhumane plot against Sir Balthazar Gerbier", waarin hij betoogde, dat hij een trouw Protestant was. Daar hen evenwel op dergelijke wijze het verblijf in Engeland onmogelijk werd gemaakt, wist hij vergunning te krijgen om het land te verlaten en vertrok naar Frankrijk, voorzien van een brief van KAREL I aan Lodewijk XIII, die evenwel, toen Gerbier in Mei I643 te Calais aan wal" stapte, reeds overleden was.

Hij richtte rich nu tot de regentes en tot MAZARIN, die hem, naar het schijnt, welwillend ontvingen, toen hij vocr den dag kwam met plannen, die hem ook reeds in Engeland bezig hadden gehouden. In de Spaansche Nederlanden was hij van nabij, wellicht ook door persoonlijke ervaring, bekend geworden met de werking van banken van lecning; aan KAREL I had hij voorgesteld inrichtingen van dien aard op te richten, waarvan evenwel niets gekomen was. Dergelijke aanbieding deed hij nu aan de Fransche regeering; bovendien deelde hij mee bekend te zijn met het bestaan eener rijke goudmijn in oostelijk Guyana, welk geheim hem tijdens zijn verblijf in Spanje door een ontevreden ambtenaar zou zijn medegedeeld. Nu trok juist in deze dagen Guyana in bijzondere mate de

1) Mededeelingen over het proces in de Cal. of State Papers, Dom. I64I p. $3^{6}$ e.v. Zie ook 1640:618,265.

2) Cal. of State Papers. Dom. Ser. I5 Juli I6 4 t. 
aandacht der Franschen. Een compagnie van Rouaansche kooplieden, die reeds vroeger emigranten naar Guyana had gezonden, zond in Augustus I 643 andermaal een drichonderdtal derwaarts. GERBIER mocht dus hopen, dat zijn voorstellen de belangstelling der regeering zouden opwekken; hij werd echter teleurgesteld, daar MazARIN niet op zijn plannen inging en hem zelfs machtigde zich tot Spanje te wenden, dat, zooals GERBILR voorgegeven had, een aanzi nlijke som voor het geheim had geboden.

Wel ging hij in op het andere voorstel, hoewel zich daartegen een sterke oppositie openbaarde. Van verschillende zijden betoogde men, dat men aan een ketter niet zulk cen belangrijke opdracht moest geven; zijn vijanden uit Brussel werkten hem ook hier tegen, terwijl de Engelsche gezant in Parijs, bezorgd dat hij door GERBIER verdrongen zou worden, ziju handelingen met argwaan gadesloeg ${ }^{1}$ ).

Met groote handigheid wist GERBIER aanvankelijk deze bezwaren te boven te komen. In een aantal vlugschriften ${ }^{2}$ ) zette hij de werking der leenbanken uiteen, wier nut volgens hem alleen door de woekeraars in twijfel lon worden getrokken. Een groot voordeel was het voor hem, dat hij enkele der voornaamste edelen voor zijn plannen won en zelfs den hertog van Orleans en den prins van Condé wist te bewegen zich aun de onderneming verbinden. Zoo scheen hij zich dan weer een schitterende positie verworven te hebben; in het jaar I645 begaf hij zich naar Holland om te trachten daar een antal aandeelen aan de markt te brengen. Niet minder dan 60 banken van leening zouden worden opgericht, welke onder zijn leiding als , surintendant-general zouden staan en verschillende contracten, in onze Notarieele Archieven bewaard, spreken nog van GERBIER's werkzaamheid ${ }^{3}$,

Zeer onverwacht, naar het schijnt, vielen al deze schoone plannen in dingen. Waarschijnlijk hebben zijn vijanden gebruik gemaakt van zijn afwezigheid om hem ten val te brengen. Hoe de zaak zich heeft toegedragen, is niet bekend; volgens meededeeling van GERBIER hadden Engelsche uitgewekenen, vooral een ${ }_{z}$ ekere WILL CRAFT of CROFT, het gerucht uitgestrooid, dat GERBIER niet do vader zijner dochters was en deze net geweld tot het Protestantisme had gebracht. Drie zijner dochters werden daarop in het Engelsche nonnenklooster Sion te Parijs gebracht; hij zelf moest zijn plannen opgeven en het land verlaten en zou zelfs

1) Evelyn: Memoirs II Addition: 265.

2) Manifeste du Chevallier Balth. Gerbier (Thysiana 4254 en 4255). Remonstrance très humble. .... touchant le mont de piété et quelques mauvais bruits que nombre d'usuriers sèment contre ce jieux, ntile et nécessaire établissement ( $\left.15_{43}\right)$. Zue verder in Danjou: Archives curieuses de l'histoire de France I ${ }^{*}$ Serie, Tome 6. Justification particulière des intendants des mont-de-piété.

Exposition sur l'establissement des monts-de-piété ( 1642$)$.

3) O. a. 6 Juni, I8 Aug. I645, Not. van Nieuwland, Amsterdam.

ro Juni " " VAN TER VEN, ", zo Juli, I2 Aug. " " van Swanenburgh, Leiden. (volgens mededeeling van J6. Bredius.) 
tusschen Rouaan en Dieppe door een aantal ruiters van zijn geld en papieren beroofd zijn.

$\mathrm{Ik}$ meen evenwel, dat er reden is om aan de juistheid dezer mededeelingen te twijfelen, die wat al te veel aan het melodrama herinneren. De dochters van GERBIER, die in katholieke streken opgegroeid en in een geheel katholieke omgeving achtergebleven waren, hebben zich vermoedelijk tijdens de afwezigheid van den vader laten bekeeren. In hoever het mislukken zijner finantieele ondernemingen het gevolg is van deze zaak en of dit niet veeleer moet worden toegeschreven aan 's mans geringe bekwaamheid op dit gebied, is voor mij niet twijfelachtig. De geheele houding van GERBIER draagt overigens niet den stempel van oprechthcid; krachtige pogingen om weer in 't bezit zijner dochters gesteld te worden, schijnt hij niet te hebben aangewend. Wel is waar gaf hij verschillende vlugsschriften over deze zaak uit, maar de titel van deze: "dernières admonitions de messire Balth. Gerbier, chevallier, à ses filles Elisabeth et Susanne" bewijst, dat hij zich al dadelijk bij het feit zelf heeft neergelegd. De ,larmes" op den band van één dezer handschriften moge een offeren aan de mode geweest zijn, ook in andere opzichten krijgt men de overtuiging, clat er in de droefheid van GERBIER een neiging tot posecren nict te miskennen valt. In elk geval heeft hij zijn dochters niet teruggekregen; nog in 1653 spreekt hij van pogingen, die hij daartoe wilde aanwenden ${ }^{1}$ ).

Het was waarschijnlijk één dezer meisjes, die wij enkele jaren later als "filie d'honneur" bij de prinses VAN Condt aantreffen en die tijdens de Fronde een belangrijke rol in de romantische vlucht der prinses heeft gespeeld. In het jaar 1650 had MAZARIN den prins vaN CONDÉ en den hertog vaN LONGUEville gevangen genomen. De burgeroorlog brak daarna met nieuwe woede uit; de Spanjaarden, door Franschen geholpen, trokken de grens over en het stond te vreezen, dat de prinses VAN CONDE, die zich te Chantilly bevond, zich aan het hoofd der ontevredenen in 't Zuiden zou stellen, waarom MAZARIN haar verzocht naar Parijs te komen. Men bracht de bode bij mejuffrouw GERBIER, die zich in het bed harer meesteres had begeven en veinsde te ongesteld te zijn om te reizen. De jonge dame, ons door een harer bewonderaars ${ }^{2}$ ) beschreven als „brune, d'une taille agréable et aisée, les yeux vifs, la bouche belle, pleine

1) De geheele zaak is mij niet recht duidelijk. GERBier geeft het tijdstip der ontvoering zecr verschillend aan; in 't eene geschrift spreekt hij van 1644 , eiders van 1646 . Op grond eener mededeeling in een pamflet van 1646 , dat de dochters in April 1645 reeds 9 manden van hem verwijderd waren, kwam ik er echter toe als datum Juli $\mathbf{1 6} 45$ aan te nemen, wat met zijn verblijf in Holland overeenstemmen zou. Vreemd is het ook, dat G. in enkele geschriften van twee, elders van drie dochters spreekt. Misschien is én spoedig uit het klooster bevrijd.

2) Mémoires de PIEkre Lener, Procurcur-général an parlement de Dyon et conseiller d'Etat (edit. Petitot) LVIII, p. 19 I c.v.

Oudi-Holland, Igo3. 
d'esprit et de gentillesse", speelde hare rol voortreffelijk. Zoo volmaakt bootste zij haar meesteres na, met haar geveinsde tranen en haar klachten over de koningin en den kardinaal, dat de zendeling van MAZARIN geen oogenblik twijfelde, vooral toen men hem bij het zoontje van den tuinier bracht, dat men de kleeren val den hertog vaN ENGHIEN had aangetrokken. De prinses had zoodoende gelegenheid om te ontvluchten en zich naar Bordeaux te begeven, waar juffrouw GERBIER zich later bij haar voegde.

Doch het wordt tijd dat wij tot GERBIER terug keeren. Na het mislukken zijner onderneming zal hij in moeielijke omstandigheden verkeerd hebben; als gunsteling van Karel I was het in Engeland ook niet geheel veilig voor hem, zoodat hij meest in het buitenland schijnt te hebben vertoefd; zoo werd bij zijn afwezigheid een huiszoeking bij hem gehouden, bij welke gelegenheid beslag op een gedeelte zijner papieren werd gelegd om voor het proces van den koning te dienen; later werden deze gedeeltclijk terug gegeven. Niet onwaarschijnlijk lijkt het mij, dat deze papieren, die hij later mondeling moest toelichten, den grondslag hebben gevormd voor het beruchte pamflet tegen Karel I ,the none-such Charles", waarin de overleden koning op de laagste wijze uitgemaakt en beschuldigd wordt het gcheim der onderhandelingen met de Belgische grooten in 1632 en 1633 aan delandvoogdes te hebben verraclen. Mocht het vlugschrift werkelijk van GEnbIrk zelf zijn, dan zou zijn handelwijze niet genoeg veroordeeld kunnen worden; ik meen het echter te moeten betwijfelen ${ }^{1}$ ).

De rustelooze plannenmaker had al spoedig nieuwe middelen bedacht om in zijn onderhoud te voorzien. Karel $I$ had in zijn rustige jaren een inrichting van onderwijs opgericht, het "Museum Minervae, dat in de stormen der omwenteling was teniet gegaan. In het jaar 1648 verspreidde GERBIER nu een uitvoerig prospectus eener ,Academye for forrain languages etc., dat in verschillende talen werd uitgegeven. In dit curieuze stuk trachtte hij de onderneming voor te stellen als van zuiver patriottischen aard. Het was de liefde tot het Engelsche volk, die hem daartoe gebracht had. Hoe verkeerd was het toch, de jongelieden tot vol-

1) De volledige titel is: The none-such Charles, his character cxtracted out of divers originall Transactions, dispatches etc. Londen, $165 \mathbf{r}$. Ik trof een exemplaar aan in het Britsch Museum. Aanvankelijl: helde ik vooral op gezag der Dict. of Nat. Biogr. tot de overtuiging over, dat het vlugschrift inclerdaad van GERBIER afkomstig zou zijn. Bewijzen hiervoor zijn mij evenwel niet bekend geworden; de stijl is verder anders dan die van zijn andere geschriften; er komen bovendien verschillende fouten in voor, die hij niet zou hebben gemaakt. Welk doel kan hij verder met dit a no n ym geschrift hebben gehad? Schreef bij het in opdracht of met medeweten der regeering, waarom zou deze dan niet, toen enkcle jaren later een door GERBIhr onderteekende verheerlijking van de Stuarts verscheen, (zie pag. 26) den sluier hebben opgelicht? Hij zelf spreekt in later tijd van het pamflet als afkomstig van Hugh Peters, Cromwell's veldprediker, wat, al is in 't algemeen op GrekBER's beweringen weinig staat te maken, in dit geval niet geheel te verwerpen is. In elk geval blijkt duidelijk, dat reeds dadelijk na de restauratie GERBIER door het hof als de scbrijver van het pamflet werd beschouwd, maar dat hij dit zelf bestreed. (Cal. of State Papers, Counsel of State I66I p. 78.). 
tooiing hunner studiën naar het vasteland te laten reizen. Bij hun terugkomst bleek dan niet zelden, dat zij enkel geleerd hadden zich op uitheemsche wijze te kleeden, terwijl hun taal van vloeken en godslastering samenhing. Hoe licht konden daarbij in deze verdorven eeuw de jongelui niet in slecht gezelschap komen van lieden, die zich tegen beter weten in als atheïsten voordoen, hoewel hun gezond verstand hun moest zeggen "qu'il $y$ a un Dieu véritable, qui est la source et la cause première de toutes choses et qui de soy mesme est de toute éternité".

Na deze uitweiding, die aantoont, dat GERBIER besloten was met den stroom der tijden mee te varen, ging hij het program der school uiteenzetten.

Dit was rijk genoeg; onderwijs zou worden gegeven in allerlei wetenschappen. Behalve de moderne talen, 't Fransch, Italiaansch, Spaansch, Duitsch en Vlaamsch, waaronder misschien het Nederlandsch moet worden verstaan, werden ook rekenkunde, meetkunde, cosmographie, geographie en perspectief onderwezen. Voorts proefondervindelijke wijsbegeerte, dubbel boekhouden en bouwkunde, "tant pour le bastiment que pour les représentations magnifiques, des secrets mouvements de scènes et choses semblables"; wij zien dat GERBIER niet voor niets de feesten voor Buckingham had georganiseerd. Maar vooral zocht hij te pas te brengen zijn kennis van versterkingskunst, die hij vermoedelijk bij MALRITS had opgedaan; , surtout on y enseignera ce qui est de plus excellant de la practique des mathématiques, à sçavoir les fortifications, les sièges et la diffense des places, les feux d'artifice, l'ordre des batailles et la marche des armées".

Met het nuttige zou ook het aangename vereenigd worden: ,la musique à touscher toutes sortes d'instruments, la dance, faire des armes, monter à cheval, comme aussi à combattre à cheval selon la nouvelle façon. Et s'il y a des vertueux, qui ayent enclination au dessein, à la peinture, miniature ou la sculpture ils seront aussi exactement instruits en ces sciences là'.

Bovendien zou een zaal worden open gesteld voor arme kinderen, door de overheid daartoe aangewezen, die gratis les zouden ontvangen. Elken Zaterdag zou er van $3-4$ een publieke les zijn, welke ouders of "beminnaren der deugd" zouden kunnen bezoeken ${ }^{1}$ ).

Voor 't geven van inlichtingen betreffende de nieuwe academie stelden zich de heeren WILliam KIPP, vermoedelijk GERBIER's schoonvader, en SamuEl HaRt lib beschikbaar; het prospectus eindigde met het uitspreken van de hoop, dat het bezoek der universiteiten van Salamanca, Padua en Parijs nu overbodig zou blijken.

Heeft GERBIER zich voorgesteld, dat na deze pompeuse uiteenzetting zijn leerlingen zich in zijn huis in Bethnall-Green zouden verdringen, dan is hij be-

1) Men vindt dit program "the Interpreter of the Academye for forrain Languages etc." in het Prentenkabinet van het Rijks-imuseum te Amsterdam. 
drogen uitgekomen. Hij ontmoette tweeërlei tegenwerking; sommigen trokken zijn patriottische gezindheid in twijfel, waarop hij als altijd vaardig met de pen in een vlugschrift zijn goede bedoelingen in 't licht stelde; anderen, en zij waren het gevaariijkst voor hem, lachten eenvoudig om de geheele onderneming ${ }^{1}$ ). Wat ons van het onderwijs bekend geworden is, bewijst, dat zij geen ongelijk hadden. GERBIER heeft n.l. een aantal van zijn eigen voordrachten, en ecn enkele waarin van "my academie-reader" wordt gesproken, gepubliceerd en sommige daarvan geven ons kostelijke staaltjes van het door hem gegeven onderwijs.

Om dit te kenschetsen neem ik het een en ander over uit een voordracht over Cosmographie, opgedragen aan den voorzitter van den Raad van State ${ }^{2}$ ).

$\mathrm{Na}$ eerst de beweging an den hemelbol door de aanwezigheid van Io sferen te hebben verklaard, die zich alle met verschillenden omwentelingstijd om de aarde wentelen, gaat hij over tot een beschouwing der elementen, vier in getal n.l. vuur, licht, aarde en water. Verbrandt men b.v. een groene stok, dan valt deze in zijn elementen uiteen, n.l. vuur, rook, asch en schuim. Het vuur is heet, droog en zeer licht; 't komt het dichtst bij de maan voor; daarom wendt zich' alle vuur naar boven! Het heeft daar geen kleur en is dus, hoewel 40.000 mijlen dik, onzichtbaar; de hemel is onbrandbaar. De lucht, zeer vochtig en middelmatig heet, bevindt zich onder het vuur; de bovenste luchtlaags is het heetst, zoowel door de nabijheid van het vuur en de wenteling der sferen als door de, anty peristasis, that is to say by a contrary force, which a contrary element makes strengthening it selve against a greater strength of a contrary element." Het water is zcer koud en matic vochtig. Het behoorde eigenlijk de aarde te omringen, maar is door God naar de diepten verwezen. De aarde is zeer droog en matig koud; aarde is zwaarder dan water, want een steen zinkt. Eigenaardig is het daarom, dat de regen niettemin in de aarde dringt en dat er in de aarde bronnen zijn. Deze worden echter door de zee gevoed; het zout wordt door de nauwe openingen tegenhouden! Wat de hooge ligging der bronnen en het opstijgen van het water in den bodem betreft, dit is uiterst ecnvoudig te verklaren: ,it is a motion made bij attraction."

Het merkwaardigste gedeelte van het betoog is evenwel de bestrijding van wat GERBIER het stelsel van COPERNICUS gelieft te noemen. De aarde beweegt zich noch om de zon, noch om een as. Tegen 't eerste strijdt het feit, dat wij altijd de sterren even groot zien. Bij wenteling om een as zouden alle gebouwen omver geworpen worden; vogels en wolken zouden naar 't westen vliegen; een in de

1) Zoo laat BuTLER de auteur van "Hudibras" een zijner helden per testamental zijn redevoeringen aan GERBIER vermaken om bij het onderwijs in welsprekendheid dienst te doen.

2) Second lecture on cosmography - read publiquely at Sir BalthazAr Gerbiers Academy on Bednall Green.

(K. B.) 
lucht geworpen stcen zou op een afstand van 5 of 6 mijlen neervallen en dit is immers nooit waargenomen.

„Als men de aarde laat bewegen, moet men de zon wel in het midden plaatsen, wat geheel onmogelijk is; er zijn evenwel aitijd menschen, die meer hartstocht dan verstand bezitten en dingen verdedisen die ze weten, dat onwar zijn, alleen om hun geest en welsprekendheid te doen uitkomen. Laat ons daarom God danken, die in zijn onbeschrijfelijke goedheid deze hemelen voor ons nut geschapen heef, daar $\mathrm{Hij}$ ze zelf nict noodig had; zij beschamen de blinde atheïsten, die men meer moet verafschuwen dan duivels, want de duivels erkennen ten minste God, al gehoorzamen ze hem niet".

De andere voordrachten ${ }^{1}$ ) minder curieus, zijn niettemin zeer oppervlakkig, rijk aan phrases en geven geen hoogen dunk aan het ondcrwijs. Het ging dan ook de inrichting niet voorspoedig; tevergeefs trachtte GERIIER, door de voordrachten aan verschillende hooggeplaatsten op te dragen, hun bescherming te winnen. Zijn , Art of well-speaking" droeg hij op aan het Parlement en aan ieder lid in 't bijzonder: „You are the light of the State, you are the movers of the great body of the commonwealth, you are, I say, the publicque voyce and your voyce is as the voyce of God". En deze kruipende vleitaal, onderteelscnd door, ,your most prostrate, humble and obedient servant" is gedateerd van 6 Jan. 1649. Vier-en-twintig dagen later stierf GERBier's weldoener, de ongelukkige KAREI, I, op het schavot!....

Niets mocht baten en de instelling moest bij gebrek aan deelneming worden opgeheven. Dadelijk was GERBIER echter gereed om zich op een voor hem geheel nieuw gebied te begeven; hij gaf vlugschriften uit over economische vraagstukken van actueel belang. ${ }^{2}$ ) Een er van had betrekking op de visscherij en op de lakennering der IIollanders, bejde opgekomen ten koste van die van Engeland, „Geen ander volk zou toestaan, dat vreemdelingen de visch onder zijn kustcn weghaalden; zetelde de visscherij in Engeland, dan zou zij schatten opbrengen als de mijnen van Lima en Potosi," Ook moest men den uitvoer van wol en vollersaarde op doodstraf verbinden, den invoer van ruwe zijde bevorderen en banken oprichten ten gerieve van den handel.

Misschien had hij het aan deze pamfletten te danken, dat hij in 1652 voor het comité van handel en buitenlandsche zaken werd geroepen ,to acquaint them

1) O. a. The first lecture touching Navigation (K. B.) opgedragen aan HeNRY VANe. Hierin wordt o. a. medegedeeld, dat ten tijde van keizer Tinerius in ce Arabische Zee Spaansche vlaggen werden gevonden en dat de koning van Zwitserland" aan Metellus Indianen ten geschenke gaf, die aan de Duitsche kust waren komen aandrijven.

2) Some considerations on the two grand Staple-Commodaties of England and on certain establishment wherein the publick good is very much concerned $165 \mathrm{I}$ (K. B.) A new years result in favour of the poor ( $165^{2}$ : A discovery of certain notorious stumbling blocks (I652). 
with some particulars relating to the service". Wat hij hier heeft voorgesteld, is niet met zekerheid bekend; o. a. schijnt hij het aanbod te hebben gedaan te bewerken, dat een duizendtal Ieren in Spaanschen dienst zouden treden, een in die dagen meer toegepast middel om de woelige bevolking van het Groene Eiland onschadelijk te maken '). •

Ten slotte werd hem een gratificatie van 50 Pnd toegewezen; ook kreeg hij een pas om naar het buitenland te vertrekken. Misschien is echter uit laatstgenoemde omstandigheid af te leiden, dat men zijn diensten op diplomatiek gebied had ingeroepen, ook in verband met de zending, waarmede hij zich korten tijd daarna belastte.

$\mathrm{Na}$ het uitbreken van den oorlog met de Republiek was er in Engeland een krachtige partij, die aan de mogelijkheid geloofde om de geschillen op vreedzame wijze bij te leggen. $Z$ ij werd in deze meening versterkt, toen belangrijke voordeelen lang uitbleven, terwijl de groote uitgaven voor de vloot zwaar op het land drukten en voor een groot deel door verbeurdverklaring van goederen der royalisten moesten worden gevonden. Een der voomaamste ijveraars voor den vrede was HuGo PETERs, veldprediker van CROMwell, die langen tijd. predikant bij de Engelsche gemeente te Rotterdam was geweest en den strijd tusschen beide calvinistische volken als een broederkrijg verafschuwde. Op zijn aandrang wendde GERBIER zich tot de predikanten der Nederduitsche gemeente te Londen, ten einde deze op te wekken een verzoek aan het Parlement te richten tot het hervatten der onderhandelingen. Door bemiddeling van PETERS hadden de predikanten daarop een onderhoud met Cromwell, die zich een groot voorstander van een vredelievende oplossing der geschillen toonde en hen met "seer vele extra-ordinaris beleeftheden" aanspoorde met het werk voort te gaan. Daar zij evenwel de zaak wantrouwden en bevreesd waren om in ongelegenheid te komen, maakten zij er echter geen verder werk van ${ }^{3}$ ).

Hoewel deze poging mislukt was, was toch duidelijk gebleken, dat CROMwELL niet tegen den vrede was; een sterke minderheid in den Staatsraad o.a. VANE, Witlock, Purrifrey en BOND stond daarbij aan zijn zijde; kon men daarom de Republiek bewegen een nieuw gezantschap te zenden, dan was het niet onmogelijk, dat de onderhandelingen tot resultaten zouden leiden. Zoo kwam het plan op, dat GERBIER naar de Republiek zou gaan onder voorwendsel, dat hij stappen wilde doen om zich in 't bezit te stellen van eenige lancierijen in den omtrek van Goes, die, naar hij bewecrde, aan zijn vrouw behoorden; ook heette het, dat hij pogingen zou aanwenden om zijn dochters terug te krijgen.

1) Cal. of State Papers, Counsel of State, 1651 , 18 Mrt., 28 Mei; $165^{2} 21$ Juli.

2) Verbaal van van Beverninck. den Haag, 1725, Memoriën van Dec. I653. 
Met het oog op de aan GERBIER verleende pas lijkt het mij zeer waarschijnlijk, dat de reis met medeweten van CROMWELL is ondernomen.

Zonder opzien te verwekken kon GERBIER dus Engeland verlaten en over Vlaanderen naar Zeeland reizen, waar hij in September 1652 aangekomen schijnt te zijn. Denl $14^{\text {den }}$ van die maand toch berichtte DE WITT aan VAN BEunINGEN dat "seecker persoon, met naeme GERBIER", door de Engelsche regeering naar de Republiek gezonden was; "wat deszelfs aanbrengen sal wesen, is nogh onbekent", voegde hij er aan toe ').

Het betreden van den geboortegrond schijnt op onzen avonturier een eigenaardigen invloed te hebben uitgeoefend. De man, die zoo kort geleden de Engelsche regeering tot maatregelen had aangezet, die voor ons verderfelijl hadden kunnen zijn, was nu op cens verkeerd in een vurig vaderlander, een „getrowhartich ingeboren patriot." Zoo richtte hij al dadelijk na zijn aankomst een schrijven aan de regeering van Vlissingen, om deze te waarschuwen tegen de verraderlijke "desseynen" der Engelschen. Door een toeval toch was hem ter ooren gekomen, dat deze een aantal "dangereuse" machines hadden vervaardigd; in schepen geplaatst, welke naar onze havens gezonden zouden worden, moesten deze dienen om onze vloot en havensteden te vernielen. $Z_{i j n}$ waarschuwing liet hij vergezeld gaan van een teekening met toelichting. „Door een cast van eykenhout inhoudende twee, drie, vier à vijfhondert tonnekens buspoeier, vast toegemaeclit met sterke isere banden" waren lonten gelegd. Het geheel was geplaatst in een "gemetselde machine van arduynsteen, omvattende de bovengemelte houten Casse; de steenen sijnde aen malcanderen vastgemaeckt met iscre platen in loot gegoten, in dewelcke boven de hondert bombes sijn. 't Gemetsel van den bodem is vier voeten dick, weder sijden aght, boven twaelf, soo dat wanneer ' $t$ vier 't cruyt raeckt, ' $t$ effect daervan is soo machtich, als dat 't schip waerinne voorgemelte machine gemetselt is (sijnde in een haven ofte dicht bij andere schepen) alles destrueert, dat daer omtrent is, jae soude de havens ende partijen van de stat neerslaen." Daarom gaf hij den raad alle aankomende schepen te visiteeren en bij ontdekking de lonten vooral niet af te trekken maar af te snijden. ${ }^{2}$ )

Dergelijke mededeelingen richtte hij ook aan andere havensteden, terwijl hij in een uitvoerige memorie aan de Staten-Generaal het doel zijner komst uiteenzette. Volgens hem was het de ontdelking dezer geheime plannen geweest, die hem bewogen had in allerijl naar 't vaderland over te steken, temeer, daar dit nog door andere gevaren bedreigd werd. Op last der Engelsche regeering

1) Brieven, geschreven ende gewisselt tusschen ce Hcor JOHAN dE WrTt ent. V I5.

2) De teeliening met toclichting is nog aanwezig in het Museum v/h Zeeuwsch Genootschap. Een bjjbehoorend schrijven vond $\mathrm{ik}$ in het gemeente-archief van Amsterdam (Missiven van particulieren, 42.) 
toch zouden een aantal waghalzen beproeven de dijken tusschen Rammekens en Vlissingen door te steken; bovendicn zou men I0,000 "roode Cromwellsche Cosacken" laten landen, voor een deel bij Scheveningen, voor cen ander deel in Groningen. Tevergeefs had hij in Engeland op het onmenschelijke dezcr plannen gewezen; toen dit niet baatte, had hij eenige vlugschriften uitgegeven tot "het pacificeren der gemoederen en de schandemaeckinge der brandstichters" ${ }^{1}$ ).

Ik vermoed, dat de Hollandsche staatslieden de mededeelingen van GerbifR wel "cum grano salis" zullen hebben aangehoord. Toch schijnen de StatenGeneraal er aanleiding in gevonden te hebben een matregel te beramen tegen de plannen der Engelschen; van welken aard deze geweest is, is niet bekend ${ }^{2}$ ).

Van meer beteekenis was echter de vraag, tot welke aanbiedingen GLRIIER gemachtigd was. Dat men zich dienaangaande geen groote verwachtingen behocfde te maken, bleek al heel spoedig uit de stukken, die hij kon overleggen. In ce eerste plaats was dit een, niet geteekende, instructie, krachtens welke hij gemachtigd heette te $z i j n$ te verzekeren „op vromen mannen woorde, wanneer Godt sal gelieven de herten van beyde de Natiën te bewegen tot een vrecusame dispositic, dat alle 't geene hem gecommuniceert is geweest, sal bevesticht worden." Verder werd in dit stuk in algemeene bewoordingen gewezen op de welwillende gezindheid van de voornaamste leden van 't parlement tegenover de Republiek. Voorts legde hij over een aanbevelingsbrief van I'ETERS aan NIEUwPOORT, waarin er vooral op gewezen werd, clat men zich niet de zaak der STUARTs moest aantrekken; "soo ghijlieden de querelle der STUARTs trowt, soo sijt ghij verloren," een waarschuwing, waarvoor wel aanleiding bestond, daar herhaaldelijk vooral door Oranjegezinden betoogd werd, dat men zich op die wijze den steun der Engelsche royalisten kon verzekeren.

Dergelijke mededeelingen konden natuurlijk moeielijk den grondslag voor nieuwe onderhandelingen vormen. DE WITT had al dadelijk weinig gewicht aan GERBIERS voorstellen gehecht; den 23sten September reeds schreef hij aan VAN BEUningen: "Mijn gevoelen is, dat daerop niet veel staets is te maecken, en dat daervan niets vruchtbaerlijcks te verwachten is". Toch brak hij de onderhandelingen niet geheel af; ook VAN BEunINGEN oordeelde, dat, al ware het gewenscht geweest cat op het, ,aanbrengen van GERBIER wat meerder fondament kon worden gemaakt, het eghter soodanich niet is, dat men het geheel kon verwerpen ende dies dat men wel gedaan heeft, 't selve aen de hant te houden. ${ }^{3}$ )

1) Verscheyden Poincten en ouvertures van den Rioder Gerbier, 29 Oct. I652, Engelant, Secrete Casse, Rijks-Archief, den Ilaag.

2) Blijkens mededeeling aan van Beuningen, Erieven V, 27 is een resolutie van dien aard genomen, die ik evenwel niet heb kunnen opsporen.

3) Brieven, geschreven ende gewisselt tusschen de heer JoHAN DE WITT enz. 23 Sept,, I2, 23 en 28 Oct, I652. 
Den $23^{\text {sten }}$ October bracht de commissie, aan wie de onderhandeling met GERBIER was opgedragen, de zaak in de Staten-Generaal ter sprake; uit de resolutiën blijkt alleen, dat de papieren in de "secrete casse" zouden wordon neergelegd, wat in dit geval zeker met een „ter griffie deponeeren” zal hebben gelijk gestaan.

Deze afloop was des te eerder te verwachten, daar de voornaamste voorstander van den vrede in Engeland tegelijkertijd door onvoorzichtigheid in groote ongelegenheid geraakte. Door zijn ijver meegesleept, had PETERS een brief gericht aan den vice-admiraal AvSCUE, om dezen aan te manen niet tegen zijn gelootsgenooten te strijden. Ayscue sympathiseerde tot een zekere hoogte met PETERs, maar achtte zich niettemin verplicht den brief aan het Parlement over te leggen, dat PETERs voor zich ontbood en hem een strenge berisping toediende. ') Begrijpelijkerwijze richtte zich het wantrouwen ook teggen GERBIER, die weldra uit Engeland de waarschuwing ontving om voorzichtig te zijn, daar zijn brieven onderschept en ontcijferd waren. PETERs, beducht om zich opnieuw te comprom. mitteeren, durfde zich niet verder met de zaak inlaten, zoodat GERBIER's brieven onbeantwoord bleven en hij het niet kon wagen naar Engeland terug te keeren, hoewel zijn zaken dringend eischten, dat hij zou overkomen ${ }^{2}$ ).

In het volgende jaar gring daarom zijn zoon GEORGE naar Londen, waar hij de mannen van de vredespartij geheel ontmoedigd vond. Hoe de stemming was, leert ons een brief door den jongen GERBtER aan zijn vader geschreven, maar door THURLoE onderschept en met diens papieren uitgegeven. Hij deelt daarin mee, dat hij zich tot de aangewezen personen hadden gewend, die hem wel wilden aanhooren, maar niet geneigd bleken brieven aan te nomen of zich verder met de zaak te bemoeien, vooral wegens het strenge verbod, door het Parlement uitgevaardigd. Vooral spreekt hij van een persoon, vermoedelijk PETERs, die de bclofte had afgelegd zich niet meer met de politiek te bemoeien en zoo schuw was als "a wall-eyed horse." Van alle zijden was hij gewaarschuwd zijn vader niet te laten overkomen, daar niemand hem zou durven of kunnen beschermen, terwijl ook de schuldeischers hem niet met rust zouden laten ${ }^{3}$ ).

Reeds geruimen tijd te voren had GERBIER zich met de gedachte vertrouwd gemaakt zich hier te lande een nieuwe positie te scheppen. In zijn memorie aan de Staten-Generaal reeds had hij zich onder verwijzing natar de diensten, die hij vroeger bewezen had, ,aan het lieve vaderlant" zijn diensten als gezant ange-

1) GARDINER: History of the Commonwealth and Protectorate JI I 28 ff.

2) Vetscheiden Poincten en Ouvertures, Ms. Rijksarchief.

3) De brief, deels in cijfors geschreven, spreekt hier van iemand, door 't cijfer rog angegeven. Ik meen, dat Cromwert bedoeld wordt. In dit geval zou deze nog in deze dagen in verbinding met Grabiek gestaan hebben. De laatste had zich vooral door de uitgave van een boek, vermoedelijk de "effets pernicieux" (zie beneden) in Engeland onmogelijk gemaakt.

Oud-Holland, I903. 
boden. Hij beriep zich daarbij vooral op zijn kennis van vreemde talen, waardoor hij zich niet van tolken behoefde te bedienen, ,die de substantieele particulariteyten verlammen encie ommiteren ende alle secreten op de clapbanck brengen." Waar hij reeds met succes twee koningen gediend had, zou hij nog met veel meerder iverige courage ageeren in des lieven vaderlandts dienste."

Kort daarna deed GERBiER een stap, die hem den terugkeer naar Engeland gcheel onmogelijk maakte. Hij gaf, met zijn vollen naam onderteekend, een pamflet in 't licht, dat een doorloopende verheerlijking der STUARTs mocht heeten: "les effets pernicieux des méschants favoris et grands ministres d'état, ${ }^{1}$ ) een poging om de nagedachtenis van verschillende vorsten schoon te wasschen en hetgeen hun ten laste gelegd wordt te laden op de schouders van hun dienaren en gunstelingen. Zoo wordt b.v. alle schuld van PIILIPS Ir, ,ce sage et dévo $t$ roi" overgebracht op ALVA, ,dont le nom va du pair avec celui d'un noir Démon," op Granvelle, ,qui harassa aussi ces peuples-là," en van DoN JUAN, ,qui entretenoyt le Roy de mensonges et ne suggeroit que des stratagèmes pour luy faire perdre ces Provinces-là pour s'enricher de leur dépouille."

Op denzelfden voet worden ook de STUaR's besproken. Vooral Karel I wordt zeer geprezen, ,prince entier, sçavant, zêlé et constant en sa rćligioion, exact en l'observation de ses traictez avec ses voysins, ferme à ses amys et serviteurs. Qui estoit en vénération aux péres de familles, un exemple très-rare de bon père et mary, que les doctes avoyent en estime à cause de son sçavoir que les vertueux consideroyent comme un modèle très-rare et acompli de toutes sortes de vertus, qui obligea les artistes à se rendre plus experts, pour ne perdre leur crédit avec luy".

De gunstelingen, vooral COTTINGTON en LAUd, "ce furieux archévesque, worden daarentegen voor alle onheil aansprakelijk gesteld: „ils doivent passer pour des monstres abominables, pernicieux et damnables". Zoo dragen zij de schuld, dat in het rampzalige eiland de kerken ontwijd zijn, dat het atheïsme alom verspreid is en dat er allerlei ongercchtigheden voorvallen onder den dekmantel cener geveinsde vroomheid.

Het pamflet eindigt met een oproeping aan alle souvereinen en volken van Europa om zich te vereenigen tegen de Engelsche ketters en het is dus geen wonder, dat het boekje in Engeland verboden werd ${ }^{2}$ ). De vraag doet zich bij

1) den Haag 1653 (Kon. Bibl.)

2) Bijkens een aanteekening in het excmplaar der Kon. Libl. Gerbier deelt ten slotte mee, dat hij in een vervolg nog verschillende andere punten bespreken wil o.a. "le preuve indisputable de la chasteté de la reine", alsmede "l"enrichissenent dcs parlementizires". Naar het schijnt is dit gedeelte nimmer verschenen. WALPOLE noemt in zijn "Anecdotes of painting" het pamflet "an ignorant, service rhapsody containing little argument, many lies and some curious facts, if the author is to be bclieved." 
ons voor, wat doel GERBIER met deze uitgave heeft gehad. Moeten wij er cen uiting van wrakkzucht in zien tegen de bovendrijvende partij gericht, of meende hij, dat het getij zou keeren, zoodat het zaak was te trachten tijdig bij KAREL II in 't gevlei te komen? Het latste komt mij het meest waarschijnlijk voor; hij is echter in dit geval teleurgesteld en gedwongen naar andere middelen om te zien om in zijn onderhoud te voorzien.

Aan pogingen hiertoe liet hij het dan ook niet ontbreken. Allerlei oude plannen haalde hij weer op en trachtte ze nu in ons land te verwezenlijken. Zoo spreekt hij in een werkje "Crijghsarchitecture ende Fortificatiën" ") over de oprichting cener "publicque constleerplaetse" te Middelburg, welke blijkens het leerplan een scort polytechnische school zou worden; onbemiddelden zouden hier gratis, anderen voor één derde der gewone kosten het onderwijs kunnen volgen. Eenigen tijd later gaf hij een werkje uit "Secretum vertutum ou miroir de la vertu", waarin hij aangaande de meest verschillende punten zijn kennis lucht, en zoowel bijbelteksten als verschillende systemen van geheimschrift verklaart ${ }^{2}$ ).

Ook vinden wij de veronderstelling uitgesproken, dat GERBIER in dezen tijd als tusschenpersoon tusschen CROMwell en den Prins van Condé zou zijn opsetreden. Het is Doubleth, het door Fruin's studie zoo bekende lid der Chambre-mi-partie, die zulks mededeelt vooral op grond van het feit, dat GERBIER"s dochter in de omgeving der prinses van Condé vertoefde. Doubletin maakt hiervan in zijn dagboek ${ }^{3}$ ) melding naar aanleiding van een ontmocting met de vrouw van Gerbier, die, bij een bezoek aan haar dochter, tc Mechelen kennis maakte met de leden der Chambre-mi-parti en hun godsdienstoefening bijwoonde. $\mathrm{Zij}$ werd met veel voorkomendheid behandeld. DoubleTh bracht haar met zijn karos van de godsdienstoefening naar haar logement terug, Mevrouw CLANT, die anders nog al trotsch schijnt geweest te zijn, presenteerdc haar tijdens de predicaties de "hooger plaetse". Vermoedelijk zou zij dit niet hebben gedaan, voegt DOUBLETH er spottend aan toe, ,soo sij van begin aen hadde geweten, dat sij (Mevrouw Gerbrer) van Nederlantsche ouders, ende sulcx ontwijffelijck ten schoonste coopluyden, tot Londen geboren, getrowt was aen GERBIER van geringe conditie, in faveur gebracht bij den hertog VAN BUCKINGHAM en so ten hove in cenigh employ gekomen".

Eenigen tijd later ${ }^{4}$ ) bood onze avonturier de princessen van Oranje een handschrift aan: "Acnmerckinghon ende doen van Keysers, Koninghen, Koninghinnen, Princen, Princessen ende doorluchtige mannen cnde nopende de conste van

1) Delft, I652.

2) Nagtglas: Luevensberichten van Zeeuwen i.v. Gerbier.

3) Dagboek van DOUbLETh 28 Iebr. 1655. folio 863. Ms. Maatschappij van Letterkunde.

4) 14 Nov. 1658 . 
welspreeken, dienende tot de goede opvoedinge van Syn Doorluchtige Hoogh, den Prince van Orangiën naer het affleggen van sijne kindtsche kleeren". Het werk, in calligraphisch opzicht merkwaardig wegens het fraaie schrift, is samengeflanst uit zijn academische lezingen en zonder de minste beteekenis. Het is echter merkwaardig wegens de opdrachten, o, a. aan Amalia van Solms en Marta Stuart, waarin van den jongen prins in dezer voege wordt gesproken: „Dit kint, 't welcke draeght den naeme van hem, die met recht geseyt is te zijn geweest een Perseus aen de Nederlantsche Andromeda; wiens hoochadelicke bloet, gesproten uit keiserlicke aderen, altijts belooft een voorspoedighe vermeerderinghe des gelucks; 't welcke op sijn voorhooft vertoont de eigene voorteeckenen van den waren Mars, gelick als die van de helden sijne voorouderen, wiens mont alreede belooft te sullen spreken met meerder wijsheyt, dan oyt gedaen heeft de Pallas der Poëten ende die 't sijner tyds aen de Chrijchsbenden Christelijcker ende moedigher een hert in 't lijff sal spreeken, dan wel selfs een vechtende Bellona soude connen doen'.

Dit boek, welks opdracht van 14 Nov. 1658 is gedateerd, komt nog in de Koninklijke I3ibliotheek voor even als een ander op dezelfde wijze samengesteld werk van GERBIER: ,princely virtuous academicall discours, concerning military architecture or fortifications, together a conference between a tutor and a page ${ }^{1}$ ), in welk laatste werk nog de handteekening van den Prins voorkomt'. Welke belooning GERBIER voor zijn vleitaal ontving, is mij niet bekend.

Ook DE WITT viel GERBIER in dezen tijd herhaaldelijk lastig met zijn voorstellen. Zoo kwam hij tijdens den Noordschen oorlog weer met zijn plannen eener helsche machine voor den dag, welke hij eerst aan WassenaAR OBdaM en daarna aan DE WITT zelf mededeelde; men zou daarmee niet alleen de vijandelijke vloot in de Sont maar zelis Stockholm kunnen verwoesten "ende alsoo een schrickelijcke diversie in syn eyghen nest maecken."

$\mathrm{Na}$ de overwinning in de Sont stond GERBIER onmiddelijk gereed met een zegezang, welke hij DE WITT toezond; tevens berichtte hij hem, dat hij een model zijner machine had vervaardigd, dat hij eenigen tijd later ,onder de roose" den raadpensionaris toezond; men kon het nu uitnemend gebruiken om de Zweedsche vloot in Lantscroon als in een val te verdistrueren". Veel voldoening had hij echter niet van zijn voorstellen; hij ontving van DE WITT taal noch teeken; ook CROMWELL trouwens, aan wien hij tegelijkertijd dergelijke voorstellen deed, achtte het vermoedelijk evenmin de moeite waard er op in te gaan 2).

1) In: De Oranje-Nassau bockerij en de Oranje Penningen in de Koninklijke Bibliotheek en in het. Koninklijk Penning-Kabinet I898. pag. 39-40.

2) De excerpten uit de correspondentie van DE WITT (2 Sept. 23 Nov. I658) werden mij uit FruIN's nalatenschap op de meest bereidwillige wijze medegedeeld door Prof. G. W. KERNKAM1. Voor de aanbiedingen aan CROMWELL zie Thurloe-papers VII 275 . 
Voor GERBIER waren deze teleurstellingen cchter van mincler beteekenis, omdat hij eindelijk een plan tot uitvoering zag komen, waarop hij de grootste verwachtingen voor de toekomst bouwde.

Wij zagen, hoe hij reeds jaren te voren aan de Fransche regeering voorstellen had gedaan aangaande de ontginning eener goudmijn in Amerika. Tijdens zijn verblijf in Spanje met Buckivgham was hij door een ontevreden Spaansch ambtenaar met het bestaan hiervan in kennis gesteld; een stuk in cijferschrift geschreven, stelde hem in staat de plaats nauwkeurig aan te geven. Hij had echter in Frankrijk geen belangstelling in zijn plannen gevonden, maar tijdens zijn verblijf in Zeeland slaagde hij er in mannen te vinden, die hun kapitaal beschikbaar stelden.

Ik heb nog slechts kort geleden ${ }^{1}$ ) de onderneming van GerbiER in Guyana in het breede behandeld en kan mij dus hier tot het aanstippen van enkele hoofdzaken bepalen. In het jaar 1656 werd een schip naar de monding der Aprouaque in het tegenwoordige Fransch Guyana gezonden om gouderts te halen. De aanwijzingen van GERBIER werden in hoofdzaak juist bevonden; het meegebrachte erts welste aanvankelijk groote verwachtingen op, maar bleek weldra waardeloos. De moed werd echter niet opgegeven, temeer daar een Nederlandsche nederzetting op het eiland Cayenne boven verwachting slaagde. Na lang geharrewar tusschen GERBIER en de participanten werd ten slotte besloten aan de Aprouaque een kolonic te stichten en zich daar zoowel op plantage-bouw als op het ontginnen der mijnen toe te leggen. In het jaar 1659 scheepte GEREIER zich met een deel zijner familie in om als "Patroon en Commandeur der Geoctroyeerde Guajaansche Colonie" aan de Wilde Kust zijn fortuin te beproeven.

Ook nu weer bleek de fortuin hem ongunstig gezind; allerlei omstandigheden deden de onderneming mislukken; vooral het slechte klimat en de oproerige stemming onder de deelnemers der expeditie; GERBIER, meer plannenmaker dan organisator, bleek bovendien niet de geschikte man om dergelijke onderneming te leiden; eer tijdlang was hij zelfs de gevangene van zijn ondergeschikten. Al twistende werd ten slotte de nederzetting verlaten, de kolonisten begaven zich naar het naburige Cayenne; Gerbier stelde zich en zijn familic onder bescherming van den waarnemenden gouverneur LANGENDICK, die te vergeefs trachtte de twisten bij te leggen.

Terwijl LANGENDIJCK moeite deed aan de Wildc kust een andere geschikte plaats voor een kolonie te vinden, had te Cayenne de catastrophe plaats. Op 't aanstoken van twee der Raden, Otтo KeyE en Rhenanus, drongen de door

1) Tijdschrift voor Geschiedenis I903, pag. I. 
drank verhitte soldaten in de woning van LANGENDIJCK door, wondden een der dochters van GERBIER en doodden een andere. Wel werd hij zelf door de te hulp geschoten kolonisten ontzet, maar de toestand was zoo onhoudbaar geworden, dat de onderneming moest worden opgegeven en de kolonisten naar 't vaderland werden terug gezonden.

$\mathrm{Na}$ zijn terugkeer scheen GERBIER aanvankelijk van plan de onderneming opnieuw aan te vatten; weer riep hij kolonisten op, om onder zijn leiding een nieuwe nederzetting te stichten; tegelijkertijd maakte hij aanstalten om KEYE, die ook naar patria opgezonden was, wegens moord te vervolgen. Van deze plannen is echter niets gekomen. Men schreef het jaar I660; de anarchie, die in Engeland sedert den dood van CROMweIL heerschte, makkte eindelijk de terugkeer der STUARTS mogelijk. Optimistisch als altijd, meende Gerbier, die zich als slachtoffer van zijn trouw aan den koning scheen te beschouwen, dat zich nu voor hem een nieuwe toekomst opende. In het pamflet, waarin hij zijn wederwaardigheden in Amerika en den droeven dood zijner dochter mededeelde, trachite hij zich reeds den weg tot het hart van den nieuwen koning te effenen. Aan zijn stervende dochter Catherina legde hij de volgende woorden in den mond:

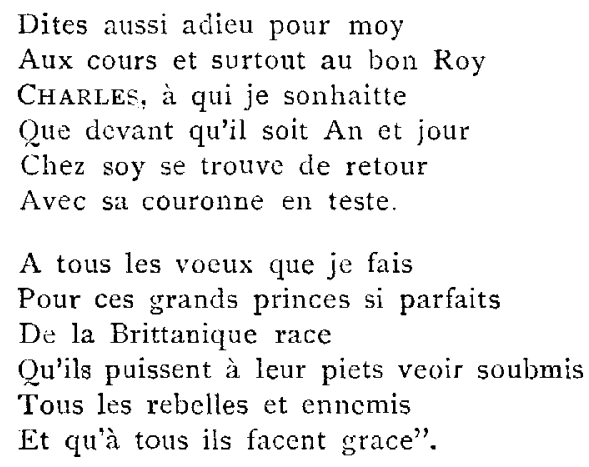

Bovendien zond hij een paar geschriften naar Engeland, waarin hij wees op de groote voordeelen, die kolonisatie in de heeteluchtstreek aanbood, blijkbaar een excerpt uit een Hollandsch boekje van KEYE; aan den koning richtte hij bovendien "A humbly Remonstrance, concerning expedients whereby His Sacred Majesty may increase his revenue with great advantage to his loyall subjects."

Toch was hij met bittere gevoelens vervuld, toen hij zich eindelijk in Dec. $1660^{1}$ ) gereed maakte om ons land voor goed te verlaten en naar Engeland over te steken. In een brief aan DE WITT, die hij in deze dagen nog herhaaldelijk met requesten schijnt te hebben lastig gevallen, lict hij nog ecnmaal zijn

1) Hij kan dus nict, zooals WALPOLE meedeelt, de ontwerpen voor de eerebogen voor den intocht van KAREL II hebben gemaakt. 
klachten hooren over de miskenning, die hem, naar hij mcende, ten deel gevallan was. „UEd., dic mach wel weten, dat ick meer van mijn vaderlandt verdient hebbe"... Mocht men hem nog van noode hebben, "noch leeft de man, die diensten soude connen doen, hoe contrary de tyden geweest sijn, Ick en can mijn persoon door den Oostenwindt niet laten naer Engelandt vervoeren, sonder van 't vaderlandt scheydende aen UEd. myn clachtliedt te laten hooren." ")

In Engeland waren nieuwe teleurstellingen zijn deel. Weldra hoorde hij dat het Zijne Majesteit behaagd had hem te ontheffen van zijn post als ceremonie-meester. De kruipende vleitaal, waarmee GERBIER aan zijn academie de gunst der parlementspartij had willen verzekeren, had de STUARTs natuurlijk zeer geërgerd; bovendien werd hij algemeen aangezien voor den auteur der "None-such Charles", dat heftige smaadschrift, 't welk alleen met kennis der papieren van GERBIER saamgesteld kon zijn, doch dat hij, zooals wij vroeger zagen, aan de pen van Hugo Piters toeschreef. Ook zijn verzoek tot terugbetaling van indertijd voorgeschoten gelden, naar zijn zeggen 4000 Pnd. bedragend, werd niet toegestaan. Tevergeefs ook wendde hij zich tot den koning met voorstellen tot het stichten eener volkplanting in Jamaica, die, als men aan vreemdelingen vrijheid van conscientie, "a prevalent bait to all men", wilde toestaan, tot grooten bloei zou geralsen. Wilde men een som van 600.000 Pncl beschikbaar stellen, dan zou hij den koning in 't bezit stcllen van schatten als die van Lima en Potosi. $\left.{ }^{2}\right)$ Een andere keer weer stelde hij voor een eiland bij Tandjer te koloniseeren of bank-instellingen te stichten; daarna kwam hij met grootsche plannen voor den dag tot verfraaing van Londen en tot verbetering der stadsreiniging. Hij wilde o. a. een poort bij $\mathrm{T}$ cmple-bar oprichten en Flectstrect en Cheapside ophoogen en richtte betreffende deze zaak zelfs petities tot het Parlement.

Van al deze plannen kwam evenwel niets; zij schijnen hem echter zekeren naam als bouwkundige verschaft te hebben; Lord CRAVEN belastte hem ten minste met het ontwerpen van teekeningen voor zijn huis Hampstead-Marshall in Berkshire; ook de uitvoering der plannen werd hem opgedragen. Het gebouw wordt door een tijdgenoot ${ }^{3}$ ) als ,inconceavably ugly" gequalificeerd, zoodat ook als architect zijn talenten waarschijnlijk niet groot geweest zijn. Toch voelde hij zich onmiddelijk verplicht zijn kennis te luchten door het publiceeren van ,A brief discourse concerning three principles of Building" en een "Counsel and advice to all Buil-

1) Gerpier aan ve WiTr, 7 Dec. 1660 , volgens mededecling van Prof, KekNkAMp vit het manuscript FRUIN der brieven van DE WITT. Het request zal vermoedelijk met de zaak KEYE in verband staan.

2) Cal. of State Pafers. Col. Series, America and West-Indies I I Jan. I662.

) Dallaway Brittannia Illustrata $f$, I 714 , geciteerd bij WALPOLE. 
ders", twee werkjes, die op architectonisch gebied al heel weinig beteekenen, maar interessant zijn wegens de opgave van prijzen van allerlei bouwmaterialen en loonen. ") Ook schijnt hij zich in dezen tijd op de stenografie te hebben toegelegd waarvoor hij een handleiding bij zijn uitgever verkrijgbaar stelde.

Zoo bleef hij werken en plannen maken tot het einde. Nog in $166_{5}$, toen hij hoorde, dat de hertog van Monmouth op reis dacht te gaan, stelde hij in allerijl een Subsidium perigrinantibus, or an assistance to a traveller in his conversation with Hollanders, Germans, Venetians, Italians. Spaniards and French, samen, een wonderlijke rhapsodie van allerlei opmerkingen zonder een spoor van geest maar overvloeiend van kruipende vleierij jegens den hertog van Monmouth.

Doch eindelijk zou ook voor dezen rustelooze de tijd van rust aanbreken. In het jaar $\mathbf{1} 667$ overleed hij, vermoedelijk terwij 1 hij het toezicht hield op den bouw van Hampstead Marshall, en werd in de kerk aldaar ter aarde besteld.

Met GerbIER daalde een merkwaardig man ten grave. Merkwaardig vooral wegens de rol, die hij in tal van belangrijke aangelegenheden heeft gespeeld, merkwaardig ook door zijn relaties tot tal van bekende personen. De rol, die hij gespeeld heeft, was dikwijls niet eervol; door zijn onbetrouwbaarheid, zijn neiging om onder alle omstandigheden de huik naar den wind te hangen, zijn streven om desnoods door de kruipendste vleitaal zich de gunst der bovendrijvende partij te verzekeren, wekt hij bij herhaling onze walging op.

Toch was hij vermoedelijk meer zwak dan slecht. Eenmaal aangegrepen door de zucht om ten koste van alles, ook van zijn eer, een belangrijke rol te spelen, was hem bij zijn middelmatige talenten en bij zijn groote zelfoverschatting van te voren een smadelijk fiasco verzekerd. Had hij de werkkracht en de energie, die men hem niet ontzeggen kan, op één zaak gericht, hij zou zich zelf en zijn familie veel teleurstellingen bespaard hebben.

Omtrent het lot zijner kinderen is weinig beliend; zijn zoon GEORGE GERBIER schijnt een tooneelstuk uitgegeven te hebben "The false favourite disgraced and the reward of Loyalty"; zijn dochters, die tot diepe armoede vervallen schijnen te zijn - het adres spreekt van ,relief from the extremities af their starving condition" - richtten later een verzoekschrift aan KAREL II tot teruggave van 4000 Pond, die hun vader nog steeds van KAREL I te vorderen had.

1) Bedoelde geschriften zijn in de Kon. Bibl, te vinden.

2) Directing him, after the latest mode to the greatest honour, pleasure, security and advantage in his travells, written for a Princely Traveller for a vademecum (Kon. Bibl.)

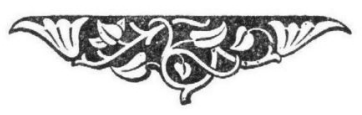

